\title{
Influence of Filler Alloy on Microstructure and Properties of Induction Brazed Al/Cu Joints
}

\author{
Xuegang Wang ${ }^{a} *$ (D), Xianjing Chen ${ }^{b}$, Xingdong Yuan ${ }^{a}$ \\ ${ }^{a}$ Shandong Jianzhu University, School of Materials Science and Engineering, Jinan, 250101, \\ Shandong, China. \\ ${ }^{b}$ Shandong Institute for Product Quality Inspection, Jinan, 250102, China.
}

Received: December 06, 2021; Revised: February 06, 2022; Accepted: February 10, 2022

\begin{abstract}
This work aimed to clarity the influence of filler alloy on microstructures and properties of induction brazed $\mathrm{Al} / \mathrm{Cu}$ joints. It was found that the alloying elements in the filler alloy changed the morphology and phase type of interfacial layer in the joint. $\mathrm{Mg}$ converted the native $\mathrm{Al}_{2} \mathrm{O}_{3}$ film into $\mathrm{MgO}$ and stopped the re-oxidation of aluminum. However, excessive $\mathrm{Mg}$ caused planar inter-metallic compounds (IMCs) to become wavy, which decrease the ductility of the joint. A suitable amount of $\mathrm{Cu}$ and $\mathrm{Si}$ removed residual oxide film and resulted in a thin planar IMCs layer, which is beneficial to $\mathrm{Al} / \mathrm{Cu}$ joint. Al-8Si-4Cu-2Mg-1Ga-0.05Ce filler foil produced an excellent joint consisting of a $2 \mu \mathrm{m}$ $\mathrm{Cu}_{9} \mathrm{Al}_{4} / \mathrm{CuAl}_{2}$ planar layer and free from oxide film. The tensile strength of the joint is higher than that of aluminum. The bend angle is higher $130^{\circ}$. The electrical resistivity of the joint is lower than the theoretical value.
\end{abstract}

Keywords: Copper, aluminum, induction brazing, inter-metallic compound, filler alloy.

\section{Introduction}

Copper and aluminum have excellent electrical conductivity. Joining of copper to aluminum is often required to transport electric current in many application fields, such as electric vehicles, high-speed railway and power grid. Mechanical connections cannot provide reliable current transmission because the oxide film on aluminum surface can cause the high contact electric resistance. Welding is more suitable for joining $\mathrm{Al}$ and $\mathrm{Cu}$ than mechanical joining due to its metallurgical reaction. However, inter-metallic compounds (IMCs) will present in the $\mathrm{Al} / \mathrm{Cu}$ welded joints in the form of $\mathrm{Cu}_{\mathrm{x}} \mathrm{Al}_{\mathrm{y}}$. These IMCs can affect the mechanical properties and electrical properties of $\mathrm{Al} / \mathrm{Cu}$ joints owing to their brittleness and resistivity characteristics. Many works have focused to control the IMCs by optimizing welding process parameters ${ }^{1-7}$. Inserting a filler material between $\mathrm{Al}$ and $\mathrm{Cu}$ is one good method to adjust the phase type, thickness and morphology of $\mathrm{Cu}_{\mathrm{x}} \mathrm{Al}_{\mathrm{y}}{ }^{8}$. Meantime, it is helpful to prevent aluminum and copper from re-oxidizing when welding under non-vacuum condition. Some pure metals and alloys have been tried as filler materials to limit the harmful effect of IMCs on the joint properties, such as Ni,Ti,Zn,Zn-Al and Al-Si.

$\mathrm{Ni}$ and Ti have high melting point and do not react with $\mathrm{Cu}$ and $\mathrm{Al}$, which can prevent the formation of $\mathrm{Cu}_{\mathrm{x}} \mathrm{Al}_{\mathrm{y}}$ during welding of copper to aluminum. Yang et al. ${ }^{9}$ reported that $\mathrm{Ni}$ can prevent the formation of $\mathrm{Cu}_{\mathrm{x}} \mathrm{Al}_{\mathrm{y}}$ in the brazed joint, but a new AlNi formed in the joint. AlNi IMC became a source of crack initiation and caused brittle fracture of the joint, thereby decreasing the tensile strength. Further work showed that a few microns thick $\mathrm{Al}_{3} \mathrm{Ni}$ layer in diffusion bonded $\mathrm{Al} / \mathrm{Cu}$ joint reduced the joint tensile strength ${ }^{10}$. Sahu et al. ${ }^{11}$ found that although $\mathrm{Ni}$ and $\mathrm{Ti}$ interlayer prevented the formation of

*e-mail: wxuegang@163.com
$\mathrm{Cu}_{\mathrm{x}} \mathrm{Al}_{\mathrm{y}}$ during friction stir welding, they became an initiation point of failure and reduced joint ductility.

$\mathrm{Zn}$ has low melting point and high diffusion rate. It can react with $\mathrm{Cu}$ and $\mathrm{Al}$ to form $\mathrm{Cu}_{\mathrm{x}} \mathrm{Al}_{\mathrm{y}} \mathrm{Zn}_{\mathrm{z}}$ and then limit the formation of $\mathrm{Cu}_{\mathrm{x}} \mathrm{Al}_{\mathrm{y}}$. Zhang et $\mathrm{al} .{ }^{12}$ believed that the formation of $\mathrm{Cu}_{\mathrm{x}} \mathrm{Al}_{\mathrm{y}} \mathrm{Zn}_{\mathrm{z}}$ by $\mathrm{Zn}$ interlayer was due to no binary $\mathrm{Al}_{\mathrm{x}} \mathrm{Zn}_{\mathrm{y}}$ in Al-Zn binary diagram. Further work showed that both $\mathrm{Al}_{\mathrm{x}} \mathrm{Cu}_{\mathrm{y}} \mathrm{Zn}_{\mathrm{z}}$ and $\mathrm{Cu}_{\mathrm{x}} \mathrm{Al}_{\mathrm{y}}$ formed in the friction stir welded $\mathrm{Al} / \mathrm{Cu}$ joint with $\mathrm{Zn}$ interlayer ${ }^{13}$. In friction stir spot welding of $\mathrm{Al}$ to $\mathrm{Cu}^{14-16}$, the $\mathrm{Zn}$ interlayer can change $\mathrm{Cu}_{9} \mathrm{Al}_{4}$ to $\mathrm{Al}_{4.2} \mathrm{Cu}_{3.2} \mathrm{Zn}_{0.7}$ and decrease the continuous and thickness of $\mathrm{CuAl}$ layer, and then improve the tensile shear strength of $\mathrm{Al} / \mathrm{Cu}$ joint. In ultrasonic spot welding of $\mathrm{Al}$ to $\mathrm{Cu}^{17}$, the $\mathrm{Zn}$ interlayer can lead to the formation of a eutectic structure instead of brittle $\mathrm{Cu}_{\mathrm{x}} \mathrm{Al}_{\mathrm{y}}$ thereby increasing the shear tensile strengths of the joint. In diffusion bonding ${ }^{18}$, the $\mathrm{Zn}$ interlayer can stop the formation of $\mathrm{Cu}_{\mathrm{x}} \mathrm{Al}_{\mathrm{y}}$ at low diffusion bonding temperature of $200^{\circ} \mathrm{C}$ and become nucleation point for $\mathrm{Cu}_{\mathrm{x}} \mathrm{Al}$ at high temperature of $300^{\circ} \mathrm{C} \sim 400^{\circ} \mathrm{C}$. Meanwhile, a zinc coating on copper surface can stop the copper re-oxidizing during squeeze casting of $\mathrm{Al} / \mathrm{Cu}$ bimetal ${ }^{19}$. In friction stir welding of copper to aluminum in $\operatorname{air}^{20}$, a $\mathrm{Zn}$ interlayer can eliminate the oxide film and reduce the thickness of solidified structure. Although the $\mathrm{Zn}$ filler metal can improve the joint strength, the newly formed $\mathrm{Cu}_{\mathrm{x}} \mathrm{Al}_{\mathrm{y}} \mathrm{Zn}_{\mathrm{z}}$ will reduce the ductility of the joint owing to their high hardness, synonymous of low ductility ${ }^{14}$

$\mathrm{Zn}-\mathrm{Al}$ alloy is a commonly filler metal for brazing $\mathrm{Al}$ and $\mathrm{Cu}$. The main research focused on the effect of $\mathrm{Zn}-\mathrm{Al}$ composition on the IMCs in interface layer and brazing seam. For $\mathrm{Zn}-(15 \sim 28) \mathrm{Al}$ filler material ${ }^{21}, \mathrm{Al}_{\mathrm{x}} \mathrm{Cu}_{\mathrm{y}} \mathrm{Zn}_{\mathrm{z}}$ was formed in interface layer and $\mathrm{CuAl}_{2}$ was formed in brazing seam. For $\mathrm{Zn}-(2 \sim 25) \mathrm{Al}$ filler material ${ }^{22}$, the amount of bulk $\mathrm{Cu}_{\mathrm{x}} \mathrm{Al}_{\mathrm{y}}$ 
in brazing seam was decreased with the increase of $\mathrm{Al}$ in $\mathrm{Zn}$-Al filler material. The thickness of interfacial layer and the morphology of $\mathrm{Cu}_{\mathrm{x}} \mathrm{Al}_{\mathrm{y}}$ in brazing seam were also changed with the variation of $\mathrm{Al}$ in $\mathrm{Zn}-\mathrm{Al}$ filler material ${ }^{23}$. For $\mathrm{Zn}-$ 22Al-(0.5 2)Si filler material, Si can prevent the diffusion of atoms and change the growth rate and morphology of $\mathrm{CuAl}_{2}$, which improve the corrosion resistance of the joint ${ }^{24}$. Moreover, $\mathrm{Al}_{\mathrm{x}} \mathrm{Cu}_{\mathrm{y}} \mathrm{Zn}_{\mathrm{z}}$ was formed in the interface layer when Zn-22Al-1.5Si filler material was used to ultrasonic assisted braze $\mathrm{Al}$ to $\mathrm{Cu}^{25}$. For $\mathrm{Zn}-22 \mathrm{Al}-\mathrm{xT}$ filler material, the doping of $\mathrm{Ti}$ in $\mathrm{Zn}-22 \mathrm{Al}$ filler material can limit the formation of IMCs and change the morphology of $\mathrm{Cu}_{9} \mathrm{Al}_{4}{ }^{26}$. Similarly, the addition of $\mathrm{Ce}$ in $\mathrm{Zn}-22 \mathrm{Al}-0.05 \mathrm{Ce}$ filler material can decrease the growth rate of IMCs and then increase the joint shear strength ${ }^{27}$. That is to say, adding $\mathrm{Si}$, Ti and $\mathrm{Ce}$ to $\mathrm{Zn}$-Al filler metal is beneficial to control IMCs and improve joint performance.

Al-Si alloy is another filler metal for brazing or transient liquid phase bonding of $\mathrm{Al}$ to $\mathrm{Cu}$. Weigl et al. ${ }^{28}$ found that Al-12Si filler materials decreased the local formation of IMCs and then significantly enhanced the ductility of Al/ $\mathrm{Cu}$ joint. Li et al. ${ }^{29}$ considered that it was difficult for $\mathrm{Si}$ to form IMCs with $\mathrm{Cu}$ or $\mathrm{Al}$ due to its non-metallic properties, which can control the growth of IMCs. The joint brazed with Al-12Si filler metal had the highest tensile strength and the joint brazed with Al-5Si filler metal had the highest electrical conductivity $^{30}$. In transient liquid phase bonding with Al$11 \mathrm{Si}-4 \mathrm{Cu}-2 \mathrm{Mg}$ and $\mathrm{Al}-4.5 \mathrm{Si}-1 \mathrm{Cu}-1 \mathrm{Mg}$ interlayer ${ }^{31}, \mathrm{Mg}$ had no influence on the formation of IMCs and Si decrease the thickness of IMCs by suppressing the growth of $\mathrm{CuAl}_{2}$, which lead to a high shear strength and conductivity joint.

As mentioned above, many kinds of pure metal and alloy have been tried as filler materials to control $\mathrm{Cu}_{\mathrm{x}} \mathrm{Al}_{\mathrm{y}}$ and stop oxidation during welding of $\mathrm{Al}$ to $\mathrm{Cu}$. Alloy is more suitable as filler materials than pure metals to attain high quality joint by comprehensive utilization of alloying elements. However, few works have achieved the best match of strength, ductility and conductivity of $\mathrm{Al} / \mathrm{Cu}$ joint. In this work, four Al-Si-Cu-Mg-Ga-Ce filler foils were developed to induction braze copper to aluminum. The influence of alloying elements on microstructure and proprieties of the joint was investigated, and the relationship between IMC and joint performance was also discussed.

\section{Materials and Methods}

Commercially pure copper plates in size of $5 \mathrm{~mm} \times 50 \mathrm{~mm} \times 50 \mathrm{~mm}$ and commercial pure aluminum plates in size of $5 \mathrm{~mm} \times 50 \mathrm{~mm} \times 60 \mathrm{~mm}$ were utilized for parent materials in this work. The faying surface to be brazed was $5 \mathrm{~mm} \times 50 \mathrm{~mm}$. Four different alloys were used as filler materials in the form of foil and their composition were given in Table 1. All filler foils had the same content of Ga and $\mathrm{Ce}$ and different content of $\mathrm{Si}, \mathrm{Cu}$ and $\mathrm{Mg}$.

The filler foils were made using a rapid solidification method as shown in Figure 1. Firstly, these six components were mixed according to the designated composition and arc smelted into a bulk master alloy. Then, the bulk master alloy was put into a quartz tube and induction heated to fully molten state. Finally, the molten master alloy was pushed to the rotating copper roller by high pressure argon gas. A foil was prepared by rapid cooling from molten state to room temperature solid state.

Figure 2 showed the schematic diagram of induction brazing for butt $\mathrm{Al} / \mathrm{Cu}$ joints. The induction brazing process was similar to our previous work ${ }^{32}$. The aluminum plate and the copper plate were fixed using mechanical clamps. The filler foil was inserted between the faying surfaces. An axial loading was employed to fix the filler foil and provide brazing pressure. A thermocouple was located at the Al side near the faying surface to measure the induction brazing temperature. An induction coil was installed around the outside of copper plate to supply heat energy. A distance between the induction coil and the welding zone was $11 \mathrm{~mm}$ to ensure the uniform temperature in the faying area. The welding area was covered with a flow of $30 \mathrm{~L} / \mathrm{min}$ argon gas to stop the re-oxidation of faying area. The induction brazing temperature was $590^{\circ} \mathrm{C} \sim 600^{\circ} \mathrm{C}$, which was $60^{\circ} \mathrm{C}$ higher than the melting point of filler foil. The induction

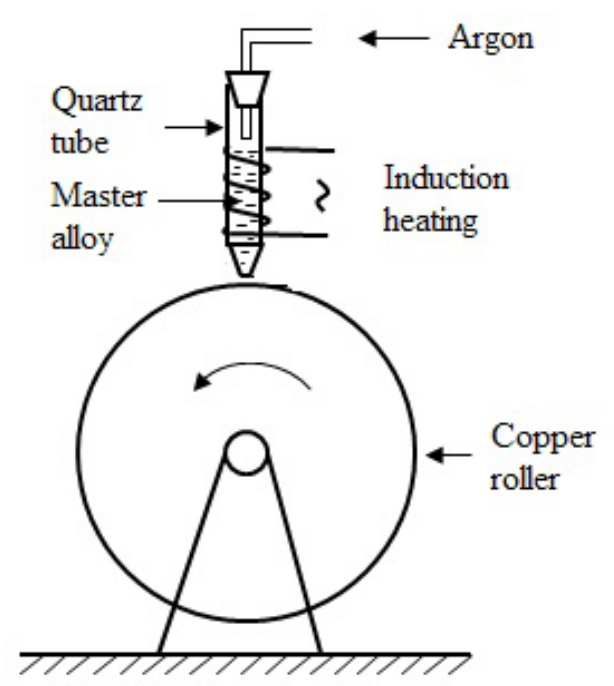

Figure 1. Sketch of rapid solidification.

Table 1. Composition of filler foils.

\begin{tabular}{cccccccc}
\hline \multirow{2}{*}{ No. } & \multirow{2}{*}{ Filler foils } & \multicolumn{5}{c}{ Compositions /weight percent } \\
\cline { 3 - 8 } & & $\mathrm{Al}$ & $\mathrm{Si}$ & $\mathrm{Cu}$ & $\mathrm{Mg}$ & $\mathrm{Ga}$ & $\mathrm{Ce}$ \\
\hline$\# 1$ & $\mathrm{Al}-8 \mathrm{Si}-2.5 \mathrm{Cu}-1 \mathrm{Ga}-0.05 \mathrm{Ce}$ & $\mathrm{Bal}$ & 8.0 & 2.5 & 0 & 1.0 & 0.05 \\
\hline$\# 2$ & $\mathrm{Al}-6 \mathrm{Si}-2.5 \mathrm{Cu}-2 \mathrm{Mg}-1 \mathrm{Ga}-0.05 \mathrm{Ce}$ & $\mathrm{Bal}$ & 6.0 & 2.5 & 2.0 & 1.0 & 0.05 \\
\hline$\# 3$ & $\mathrm{Al}-8 \mathrm{Si}-4 \mathrm{Cu}-2 \mathrm{Mg}-1 \mathrm{Ga}-0.05 \mathrm{Ce}$ & $\mathrm{Bal}$ & 8.0 & 4.0 & 2.0 & 1.0 & 0.05 \\
\hline$\# 4$ & $\mathrm{Al}-8 \mathrm{Si}-4 \mathrm{Cu}-2.5 \mathrm{Mg}-1 \mathrm{Ga}-0.05 \mathrm{Ce}$ & $\mathrm{Bal}$ & 8.0 & 4.0 & 2.5 & 1.0 & 0.05 \\
\hline
\end{tabular}


brazing time was $2 \mathrm{~s}$. The induction brazing pressure was firstly $4 \mathrm{MPa}$ before the filler foil melted and then $9 \mathrm{MPa}$ after the filler foil melted.

The filler foil and the $\mathrm{Al} / \mathrm{Cu}$ joints were characterized with scanning electron microscopy (SEM) of Hitach SU70, energy-dispersive X-ray spectroscopy (EDS) of Horiba Ex250 and X-ray diffraction (XRD) of PANalytical B.V XPert. The tensile strength and bending ductility of the $\mathrm{Al} / \mathrm{Cu}$ joints were tested using a universal test machine. The tensile specimen and the bending specimen were machined in the dimensions, $110 \mathrm{~mm} \times 12 \mathrm{~mm} \times 5 \mathrm{~mm}$ and $110 \mathrm{~mm} \times 10 \mathrm{~mm} \times 5 \mathrm{~mm}$, respectively. Both tests were carried out at room temperature

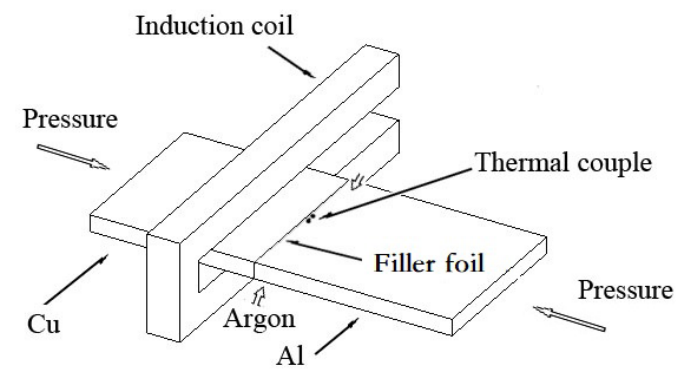

Figure 2. Schematic diagram of the setup for induction brazing aluminum to copper.

(a)

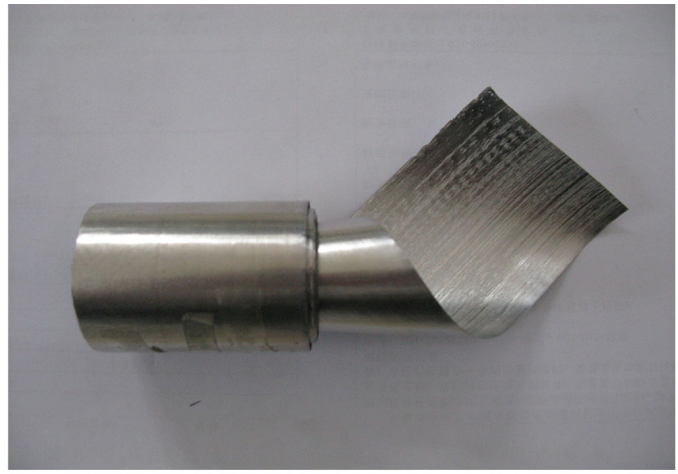

with a loading rate of $5 \mathrm{~mm} / \mathrm{min}$. The joint tensile strength as well as the joint bending ductility was obtained from the average value of three measures. The electrical resistance of the $\mathrm{Al} / \mathrm{Cu}$ joint was tested using micro-ohmmeter of Tinsley 5898 with four-point method. The electrical resistivity of the joint was then calculated based on the size of the tested sample and the electrical resistance.

\section{Results}

\subsection{Character of filler foils}

Figure 3 is the appearance of $\mathrm{Al}-8 \mathrm{Si}-4 \mathrm{Cu}-2 \mathrm{Mg}-1 \mathrm{Ga}-$ $0.05 \mathrm{Ce}$ filer foil. The filler foil is homogenous and continuous without voids. However, there is some porosity in the foil SEM image. This may be due to the fact that the surface of the copper roller is not completely flat. When the molten alloy is cooled on the surface of the copper roller to form the thin filler foil, the uneven surface of the copper roller will generate porosity on the surface of the filler foil. The porosity of the foil does not affect the brazing of copper to aluminum as the foil elements can diffuse quickly to fill the porosity during heating and then form a thin homogenous liquid layer. Other three foils have the same appearance. The melting temperature of these foil are between $530^{\circ} \mathrm{C}$ and $540^{\circ} \mathrm{C}$, and their thickness are between $60 \sim 80 \mu \mathrm{m}$.

Figure 4 shows the results of XRD and EDS of Al-8Si$4 \mathrm{Cu}-2 \mathrm{Mg}-1 \mathrm{Ga}-0.05 \mathrm{Ce}$ foil. The main phases in the foil are

Figure 3. Appearance of Al-8Si-4Cu-2Mg-1Ga-0.05Ce foil (a) photo of foil; (b) SEM of foil.

(a)

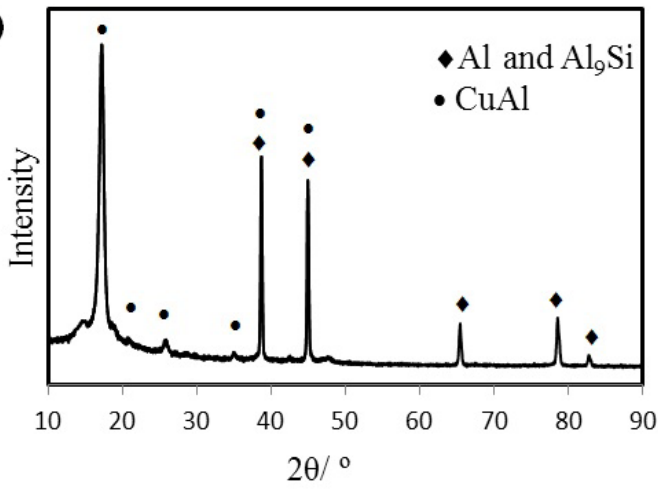

(b)

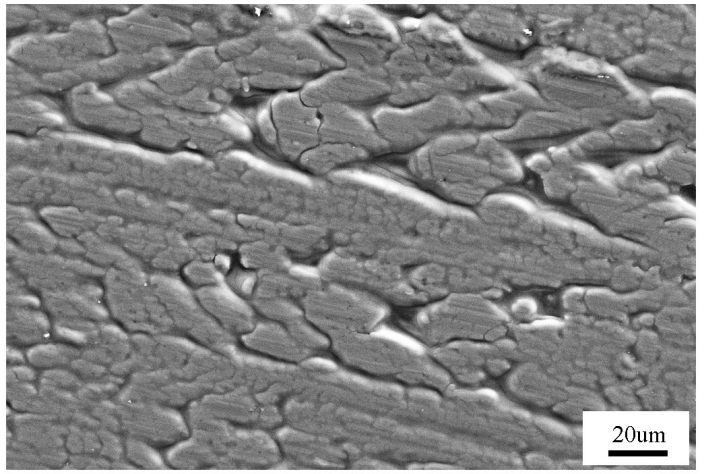

(b)

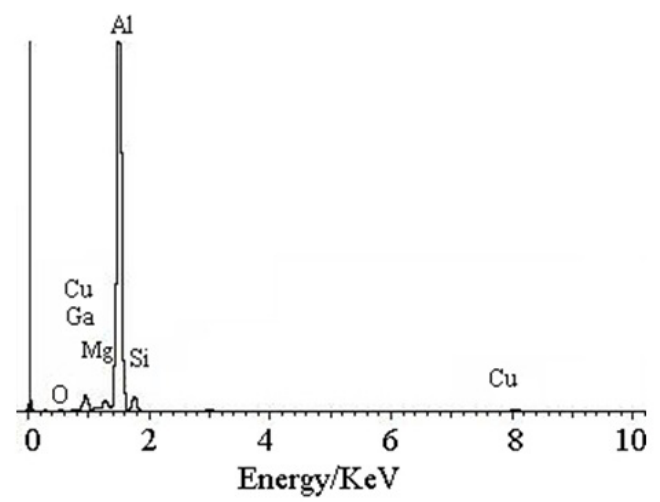

Figure 4. XRD and EDS of Al-8Si-4Cu-2Mg-1Ga-0.05Ce foil (a) XRD; (b) EDS. 
$\mathrm{Al}, \mathrm{Al}_{9} \mathrm{Si}$ and $\mathrm{CuAl} . \mathrm{Mg}$ and $\mathrm{Ga}$ are observed in the EDS, but no obvious $\mathrm{Mg}$ - or Ga-containing phases can be found in the XRD possibly owing to their low content. No Ce can be measured by EDS and XRD due to its quite low content. Other three foils have the similar results of XRD and EDS as this foil.

\subsection{Joint microstructure}

Figure 5 shows the microstructures of $\mathrm{Al} / \mathrm{Cu}$ joints induction brazed using four filler foils. A thin interfacial layer is found in all induction brazed joints. There is no eutectic phase in the joints which is different from the braze joint made by $\mathrm{Zn}-\mathrm{Al}$ filler metals ${ }^{21-27}$. The thickness of the interfacial layer is about $2 \sim 3 \mu \mathrm{m}$ for all joints, which is far less than the thickness of the filler foil with $60 \sim 80 \mu \mathrm{m}$. This indicates that the filler foil has achieved sufficient diffusion during induction brazing. In other word, this six-element filler alloy has the potential to induction braze copper and aluminum in short bonding time. The interfacial layer has four types of morphology, which are discontinuous, delamination, planar interface and wavy interface. The reason should be the different matching of alloying elements in the filler foil. The characteristics of these interfacial layers are studied in detail below.

The interfacial microstructure of the induction brazed $\mathrm{Al} / \mathrm{Cu}$ joint by $\mathrm{Al}-8 \mathrm{Si}-2.5 \mathrm{Cu}-1 \mathrm{Ga}-0.05 \mathrm{Ce}$ foil is identified using EDS and XRD, as shown in Figure 6 and Figure 7, respectively. The continuous layer on copper side is $\mathrm{Cu}_{9} \mathrm{Al}_{4}$. The discontinuous mixed layer on the aluminum side is
$\mathrm{Al}_{2} \mathrm{O}_{3}$ and $\mathrm{CuAl}_{2}$. The distribution of $\mathrm{O}$ in the interfacial microstructure shows that $\mathrm{Al}_{2} \mathrm{O}_{3}$ locates between $\mathrm{Cu}_{9} \mathrm{Al}_{4}$ and $\mathrm{CuAl}_{2}$. Xu et al. ${ }^{33}$ founded that the native $\mathrm{Al}_{2} \mathrm{O}_{3}$ was broken and located at the interface of $\mathrm{Cu} / \mathrm{CuAl}$, during ultrasonic bonding of $\mathrm{Al}$ and $\mathrm{Cu}$. Sheng et al. ${ }^{34}$ reported that the newly $\mathrm{Al}_{2} \mathrm{O}_{3}$ formed at the interface of $\mathrm{CuAl}_{2} / \mathrm{Al}$ during the heat treatment of cold rolled $\mathrm{Al} / \mathrm{Cu}$ joint. Different from these two joints, $\mathrm{Al}_{2} \mathrm{O}_{3}$ is between $\mathrm{CuAl}_{2}$ and $\mathrm{Cu}_{9} \mathrm{Al}_{4}$ in the induction brazed joint. This should be a combination of original $\mathrm{Al}_{2} \mathrm{O}_{3}$ and newly formed $\mathrm{Al}_{2} \mathrm{O}_{3}$. Although the surface of aluminum is machined before induction brazing in this work, a thin $\mathrm{Al}_{2} \mathrm{O}_{3}$ film will form immediately in air. $\mathrm{Xu}$ et al. ${ }^{35}$ reported that the thickness of the native $\mathrm{Al}_{2} \mathrm{O}_{3}$ film is about $5 \mathrm{~nm}$. The thickness of $\mathrm{Al}_{2} \mathrm{O}_{3}$ is about $1 \mu \mathrm{m}$ in this joint. This indicates that some new $\mathrm{Al}_{2} \mathrm{O}_{3}$ form during induction brazing. In other words, $\mathrm{Al}-8 \mathrm{Si}-2.5 \mathrm{Cu}-1 \mathrm{Ga}-0.05 \mathrm{Ce}$ filler foil can disrupt $\mathrm{Al}_{2} \mathrm{O}_{3}$ but cannot remove $\mathrm{Al}_{2} \mathrm{O}_{3}$ during induction brazing in non-vacuum condition. The distribution density of $\mathrm{Si}$ on copper side is higher than that on aluminum side and there is no $\mathrm{Si}$ segregation in the joint. This indicates that $\mathrm{Si}$ has diffused sufficiently from the filler foil to base metals, and the diffusion rate of Si to the copper side is faster than that of the aluminum side.

Figure 8 and Figure 9 show the EDS and XRD results of the interfacial microstructure of $\mathrm{Al} / \mathrm{Cu}$ joint induction brazed by $\mathrm{Al}-6 \mathrm{Si}-2.5 \mathrm{Cu}-2 \mathrm{Mg}-1 \mathrm{Ga}-0.05 \mathrm{Ce}$ foil. A three-layer composite structure of $\mathrm{Cu}_{9} \mathrm{Al}_{4} / \mathrm{MgO} / \mathrm{CuAl}_{2}$ is formed between copper and aluminum in the joint. $\mathrm{Cu}_{9} \mathrm{Al}_{4}$ layer is continuous, and $\mathrm{CuAl}_{2}$ and $\mathrm{MgO}$ are discontinuous. The IMCs layer is (a)

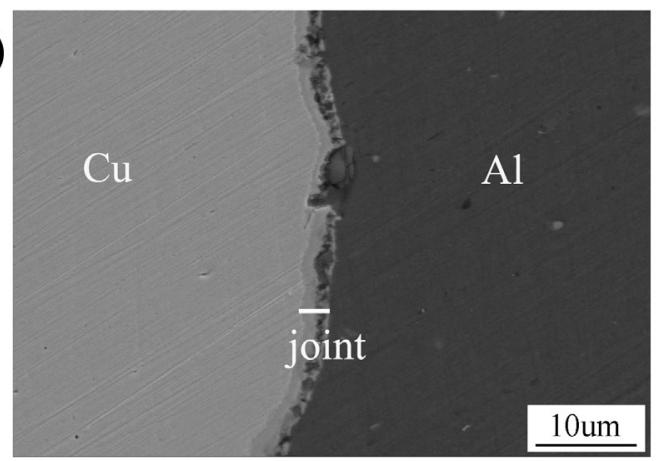

(c)

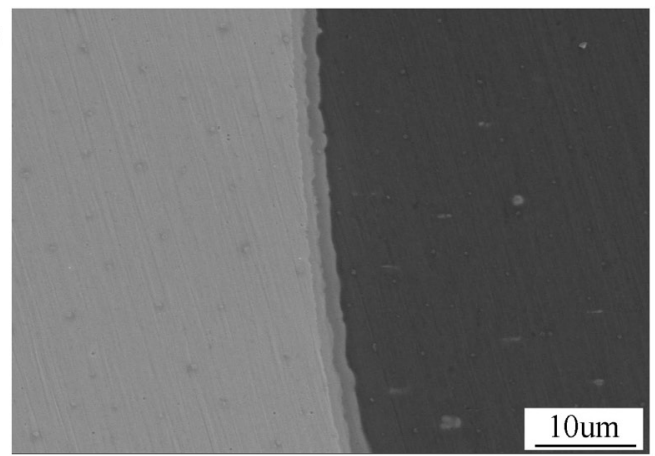

(b)

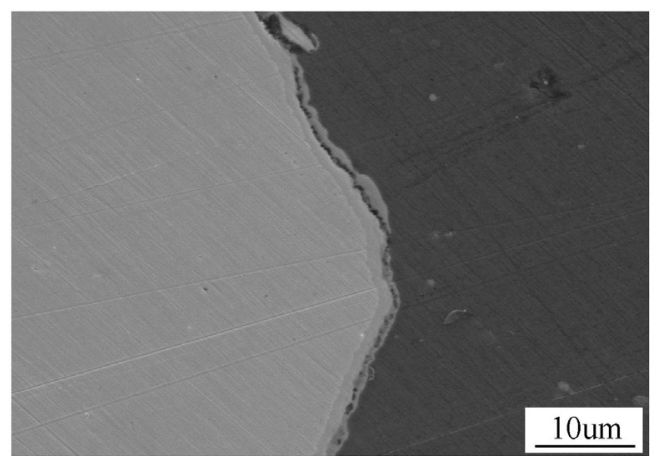

(d)

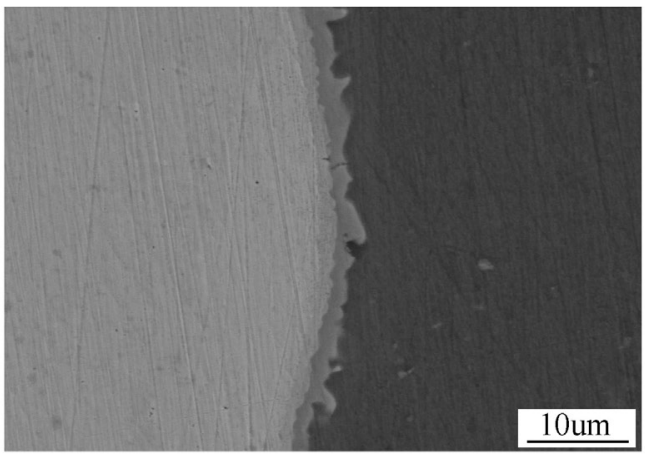

Figure 5. SEM of induction brazed $\mathrm{Al} / \mathrm{Cu}$ joints using different filler foils (a) $\mathrm{Al}-8 \mathrm{Si}-2.5 \mathrm{Cu}-1 \mathrm{Ga}-0.05 \mathrm{Ce}$ foil, discontinuous interfacial layer; (b) $\mathrm{Al}-6 \mathrm{Si}-2.5 \mathrm{Cu}-2 \mathrm{Mg}-1 \mathrm{Ga}-0.05 \mathrm{Ce}$ foil, delamination interfacial layer; (c) $\mathrm{Al}-8 \mathrm{Si}-4 \mathrm{Cu}-2 \mathrm{Mg}-1 \mathrm{Ga}-0.05 \mathrm{Ce}$ foil, planar interfacial layer; (d) Al-8Si-4Cu-2.5Mg-1Ga-0.05Ce foil, wavy interfacial layer. 
(a)

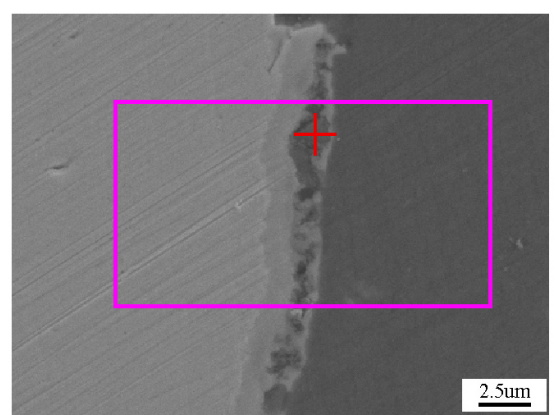

(c)

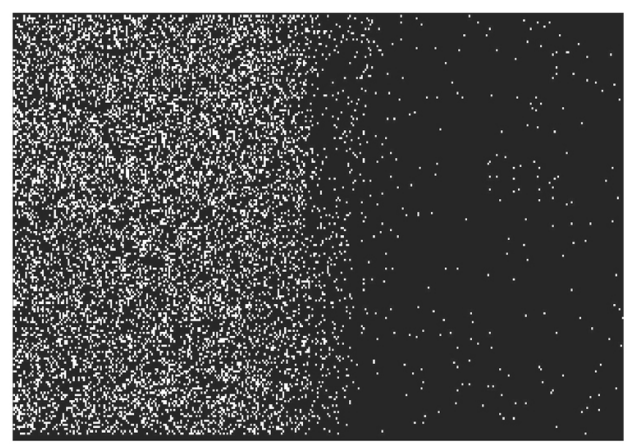

Cu Ka1

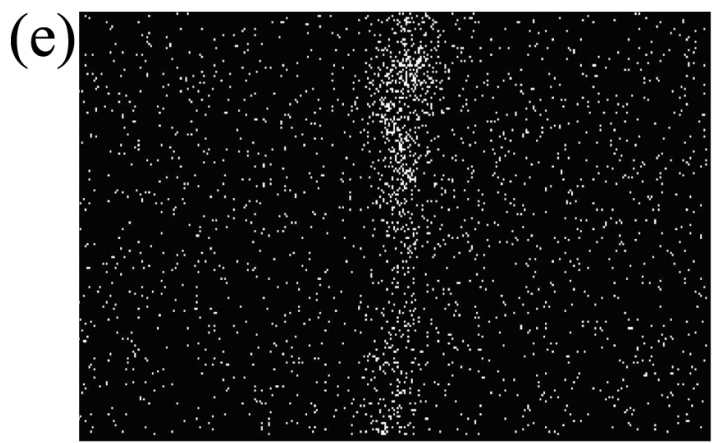

0 Ka1 (b)

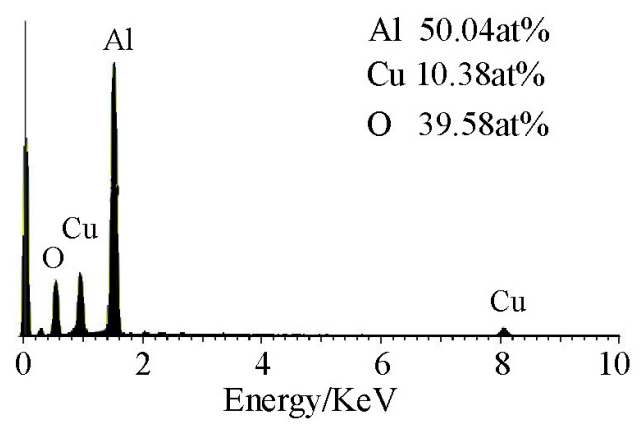

(d)

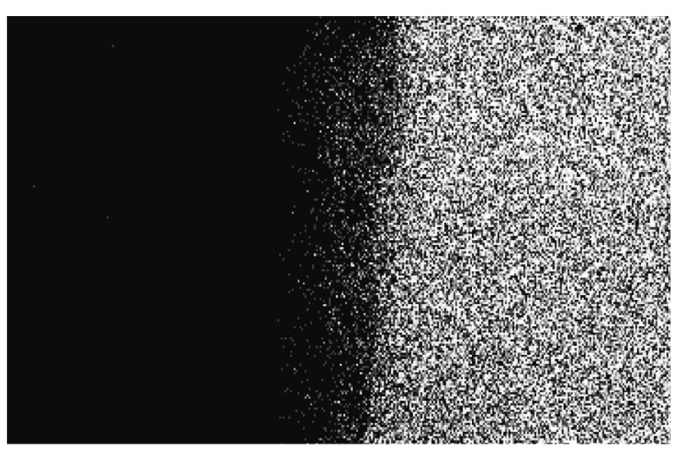

Al Kal

(f)

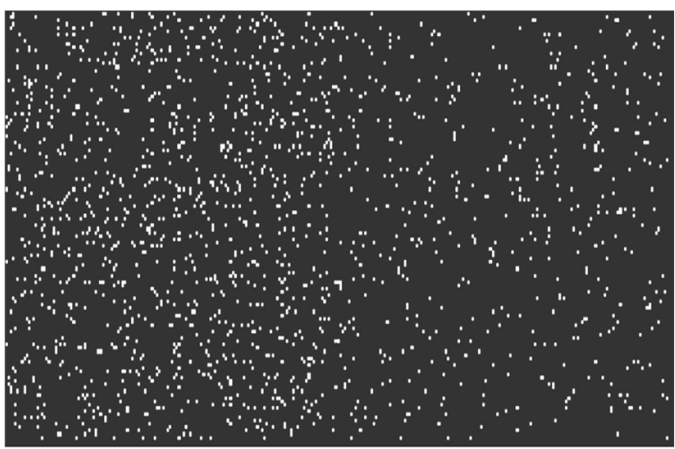

Si Ka1

Figure 6. EDS of induction brazed $\mathrm{Al} / \mathrm{Cu}$ joint by $\mathrm{Al}-8 \mathrm{Si}-2.5 \mathrm{Cu}-1 \mathrm{Ga}-0.05 \mathrm{Ce}$ foil (a) the targeted area; (b) point elemental analysis of red cross in (a); (c) elemental map of $\mathrm{Cu}$ in rectangle area of (a); (d) elemental map of Al in rectangle area of (a); (e) elemental map of O in rectangle area of (a); (f) elemental map of Si in rectangle area of (a).

(a)

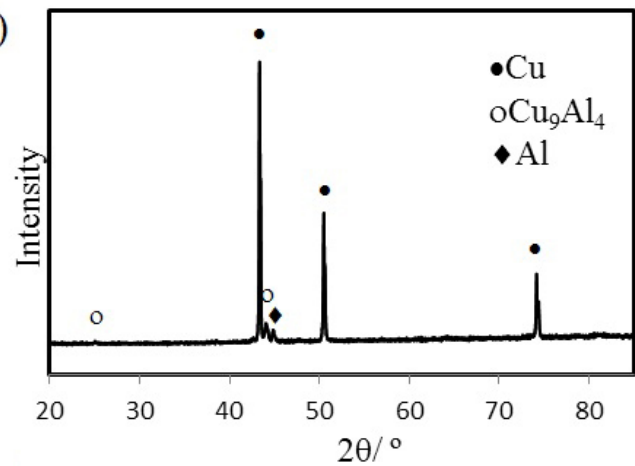

(b)

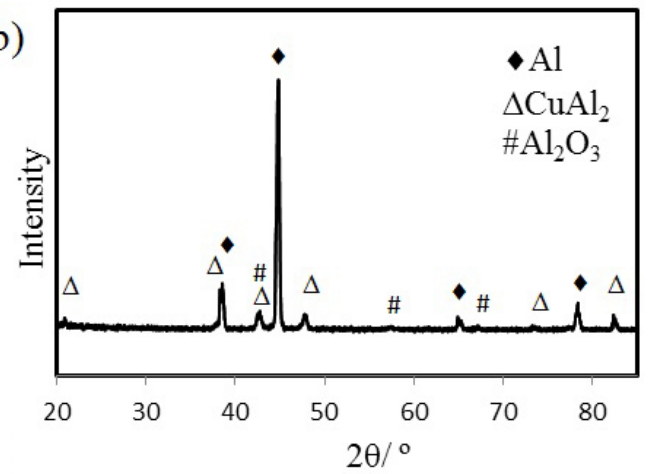

Figure 7. $\mathrm{XRD}$ of induction brazed $\mathrm{Al} / \mathrm{Cu}$ joints by $\mathrm{Al}-8 \mathrm{Si}-2.5 \mathrm{Cu}-1 \mathrm{Ga}-0.05 \mathrm{Ce}$ foil (a) $\mathrm{Cu}$ side; (b) $\mathrm{Al}$ side. 
(a)

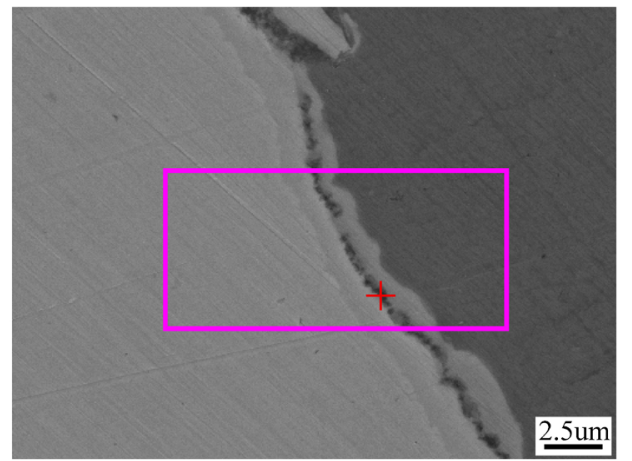

(c)

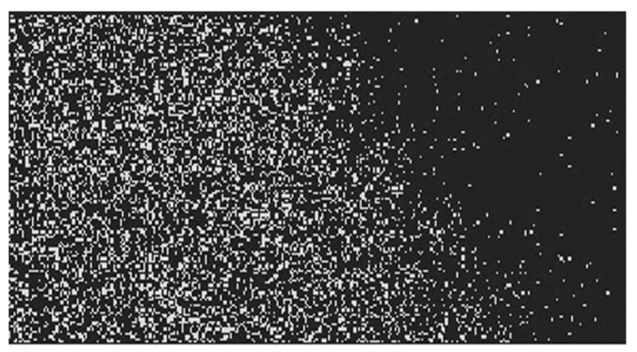

Cu Kal

(e)

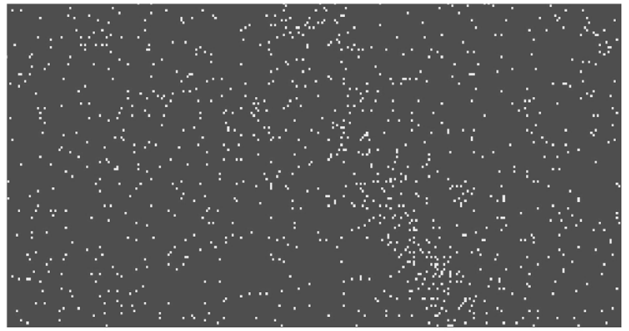

O Ka1 (b)

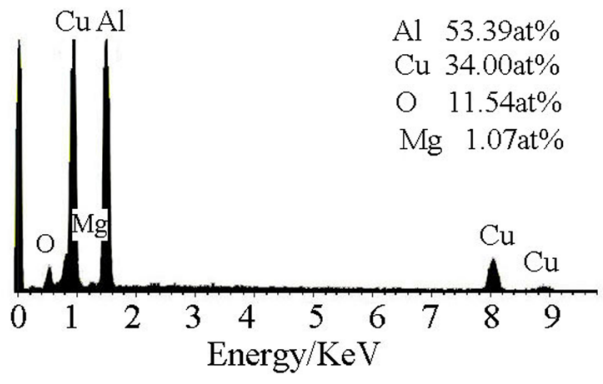

(d)

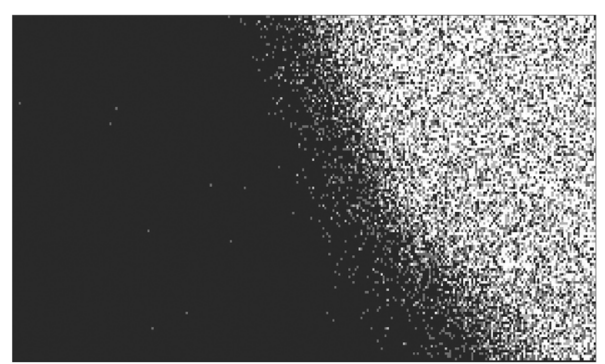

Al Kal

(f)

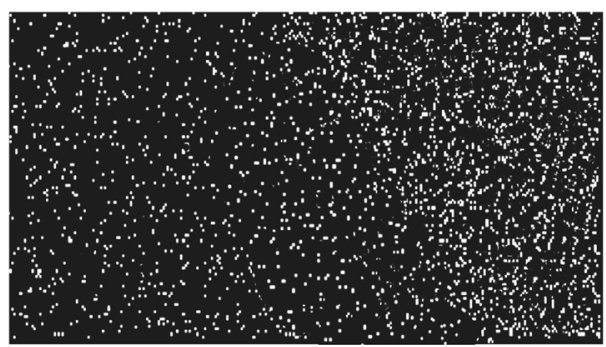

Mg Ka1-2

Figure 8. EDS of induction brazed $\mathrm{Al} / \mathrm{Cu}$ joints by $\mathrm{Al}-6 \mathrm{Si}-2.5 \mathrm{Cu}-2 \mathrm{Mg}-1 \mathrm{Ga}-0.05 \mathrm{Ce}$ foil (a) the targeted area; (b) point elemental analysis of red cross in (a); (c) elemental map of $\mathrm{Cu}$ in rectangle area of (a); (d) elemental map of Al in rectangle area of (a); (e) elemental map of $\mathrm{O}$ in rectangle area of (a); (f) elemental map of $\mathrm{Mg}$ in rectangle area of (a).

(a)

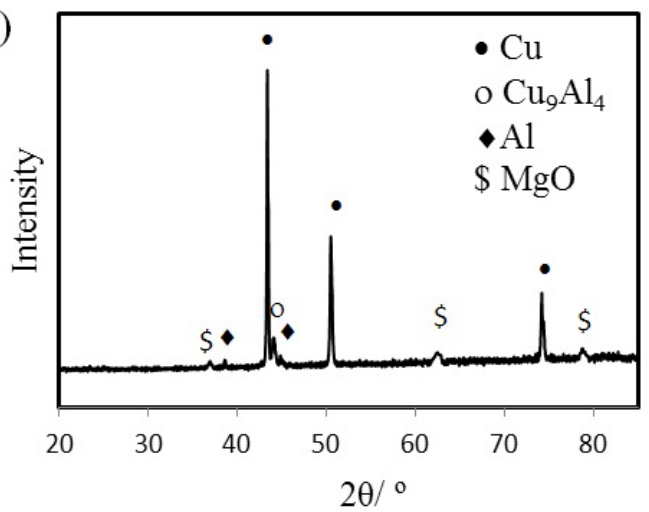

(b)

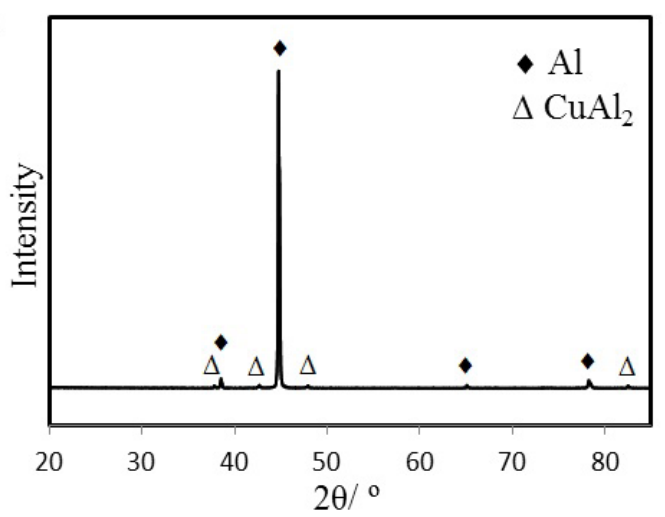

Figure 9. $\mathrm{XRD}$ of induction brazed $\mathrm{Al} / \mathrm{Cu}$ joints using $\mathrm{Al}-6 \mathrm{Si}-2.5 \mathrm{Cu}-2 \mathrm{Mg}-1 \mathrm{Ga}-0.05 \mathrm{Ce}$ foil (a) $\mathrm{Cu}$ side; (b) $\mathrm{Al}$ side. 
delaminated by $\mathrm{MgO}$. In the work by Cheng et al. ${ }^{36}$, the native $\mathrm{Al}_{2} \mathrm{O}_{3}$ film can be converted into $\mathrm{MgO}$ and $\mathrm{MgAl}_{2} \mathrm{O}_{4}$ by $\mathrm{Mg}$ during brazing of 5083 aluminum alloy. In this work, the original $\mathrm{Al}_{2} \mathrm{O}_{3}$ film is fully transformed into $\mathrm{MgO}$ when the filler foil contains $2 \% \mathrm{Mg}$ by weight. This indicates that it is beneficial to add $\mathrm{Mg}$ in the filler foil to remove the native $\mathrm{Al}_{2} \mathrm{O}_{3}$ film. Moreover, the thickness of $\mathrm{MgO}$ is greater than $5 \mathrm{~nm}$. Some $\mathrm{MgO}$ are formed during induction brazing in air because $\mathrm{Mg}$ is more active than $\mathrm{Al}$. That is to say, $\mathrm{Mg}$ in the filler foil can stop the re-oxidation of aluminum.

A two-layer interfacial structure is formed in the $\mathrm{Al} / \mathrm{Cu}$ joint by $\mathrm{Al}-8 \mathrm{Si}-4 \mathrm{Cu}-2 \mathrm{Mg}-1 \mathrm{Ga}-0.05 \mathrm{Ce}$ foil, as shown in Figure $5 \mathrm{c}$. The XRD results show that the two-layer structure is $\mathrm{Cu}_{9} \mathrm{Al}_{4} / \mathrm{CuAl}_{2}$, as shown in Figure 10. Different from the interfacial structure by $\mathrm{Al}-6 \mathrm{Si}-2.5 \mathrm{Cu}-2 \mathrm{Mg}-1 \mathrm{Ga}-0.05 \mathrm{Ce}$, there is no $\mathrm{MgO}$ in this joint. Both $\mathrm{Cu}_{9} \mathrm{Al}_{4}$ layer and $\mathrm{CuAl}_{2}$ layer have homogenous structure and planar interfaces. That is to say, more $\mathrm{Cu}$ and $\mathrm{Si}$ in the filler foil can fully extrude the newly formed $\mathrm{MgO}$ and result in a thin IMCs layer.

The XRD and EDS results of the joint induction brazed by $\mathrm{Al}-8 \mathrm{Si}-4 \mathrm{Cu}-2.5 \mathrm{Mg}-1 \mathrm{Ga}-0.05 \mathrm{Ce}$ filler foil are shown in Figure 11 and Figure 12. Similar to the joint by Al-8Si-4Cu$2 \mathrm{Mg}-1 \mathrm{Ga}-0.05 \mathrm{Ce}$ filler foil, thin $\mathrm{Cu}_{9} \mathrm{Al}_{4}$ layer and $\mathrm{CuAl}_{2}$ layer are formed between copper and aluminum. However, the interface between $\mathrm{CuAl}_{2}$ layer and aluminum is wave, as shown in Figure 5d. This indicates that excess $\mathrm{Mg}$ in the filler foil can change the interface of IMCs from planar to non-planar. Lumley et al. ${ }^{37}$ reported that more addition of $\mathrm{Mg}$ in aluminum alloys can result in expansion of the sintered aluminum alloy. Wei et al. ${ }^{31}$ reported that excessive addition of $\mathrm{Mg}$ in Al-Si filler foil can lead to a rough interface during transient liquid phase bonding of copper and aluminum. This indicates that $\mathrm{Mg}$ in the filler foil can not only remove the $\mathrm{Al}_{2} \mathrm{O}_{3}$ film, but also affect the interface morphology.

\subsection{Joint properties}

Figure 13 shows the tensile and bending properties of $\mathrm{Al} / \mathrm{Cu}$ joints made with four different filler foils. All joints are necked on the aluminum side during the tensile test, indicating that the tensile strength of all joints is higher than that of aluminum. The bending angle of all joints is different. The joint made by $\mathrm{Al}-8 \mathrm{Si}-4 \mathrm{Cu}-2 \mathrm{Mg}-1 \mathrm{Ga}-0.05 \mathrm{Ce}$ filler foil (\#3) does not fail when it is bend to $130^{\circ}$, indicating an excellent ductility. The others three joints fail when bending angle is lower than $90^{\circ}$, showing a low ductility. Based on the microstructure and mechanical properties, a (a)

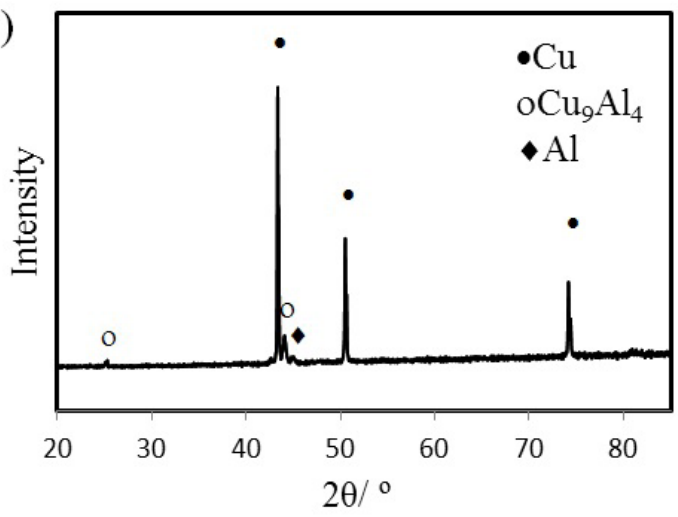

(b)

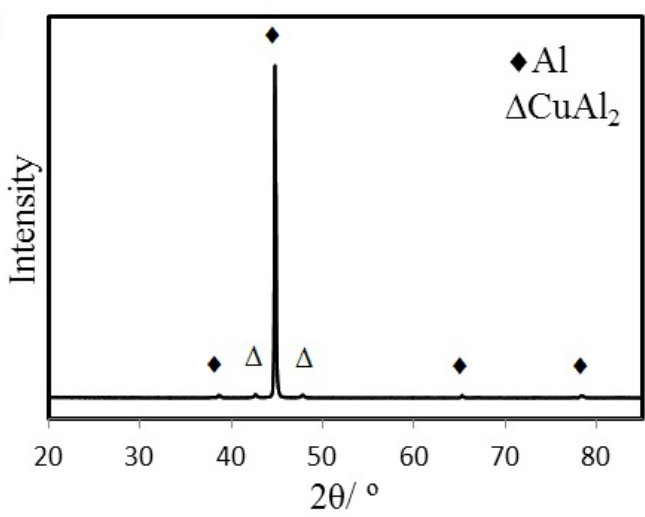

Figure 10. XRD of induction brazed $\mathrm{Al} / \mathrm{Cu}$ joints by $\mathrm{Al}-8 \mathrm{Si}-4 \mathrm{Cu}-2 \mathrm{Mg}-1 \mathrm{Ga}-0.05 \mathrm{Ce}$ foil (a) $\mathrm{Cu}$ side; (b) $\mathrm{Al}$ side.

(a)

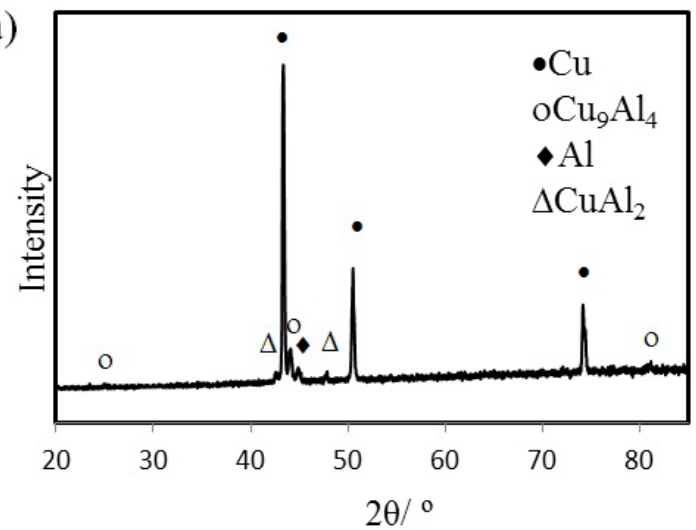

(b)

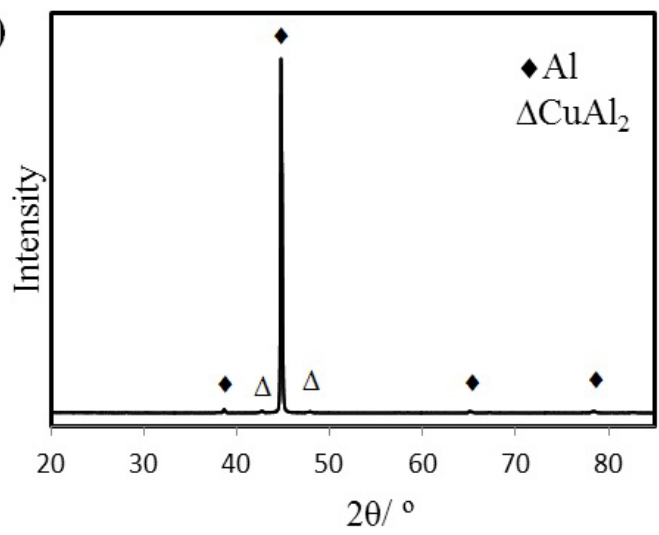

Figure 11. $\mathrm{XRD}$ of induction brazed $\mathrm{Al} / \mathrm{Cu}$ joints using $\mathrm{Al}-8 \mathrm{Si}-4 \mathrm{Cu}-2.5 \mathrm{Mg}-1 \mathrm{Ga}-0.05 \mathrm{Ce}$ foil (a) $\mathrm{Cu}$ side; (b) $\mathrm{Al}$ side. 
(a)

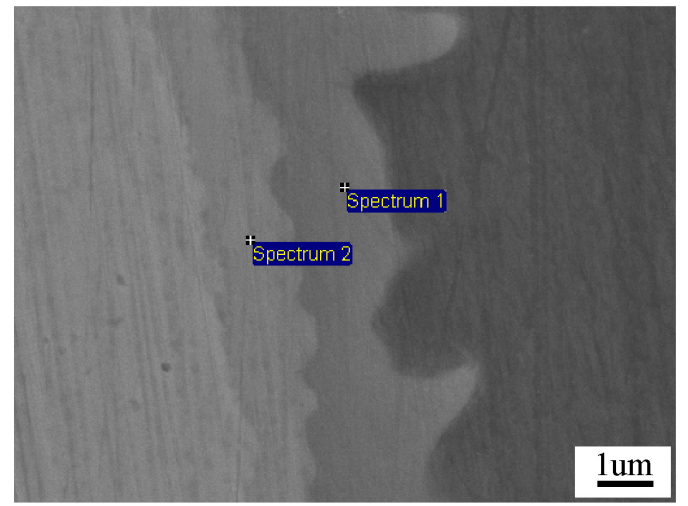

(b)

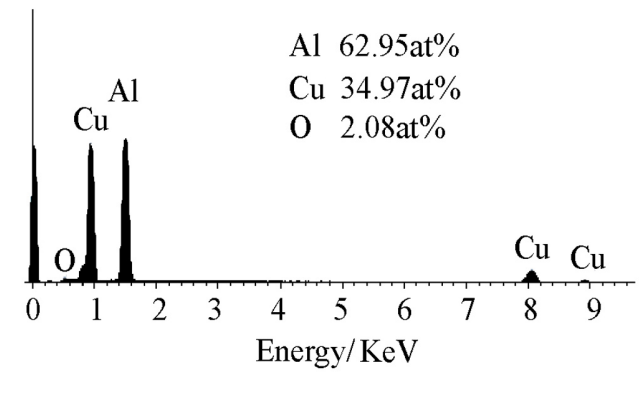

(c)

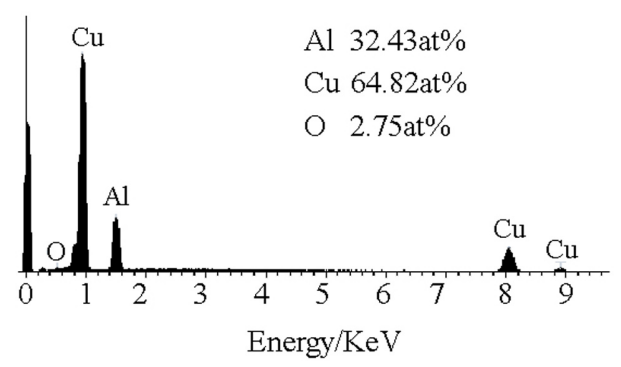

Figure 12. EDS of induction brazed $\mathrm{Al} / \mathrm{Cu}$ joints using $\mathrm{Al}-8 \mathrm{Si}-4 \mathrm{Cu}-2.5 \mathrm{Mg}-1 \mathrm{Ga}-0.05 \mathrm{Ce}$ foil (a) the targeted point; (b) point elemental analysis of spectrum 1; (c) point element analysis of spectrum 2.

(a)

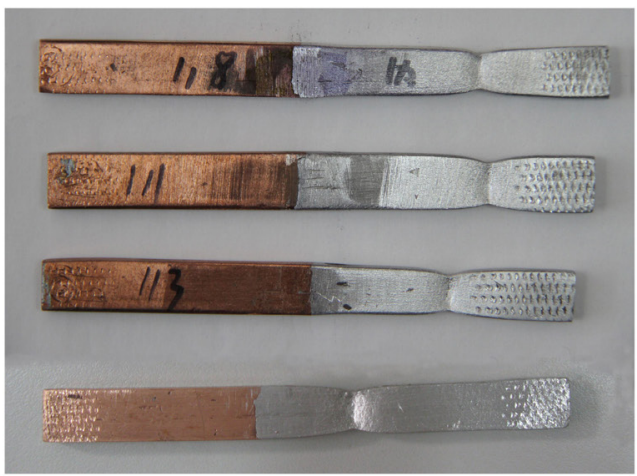

(c)

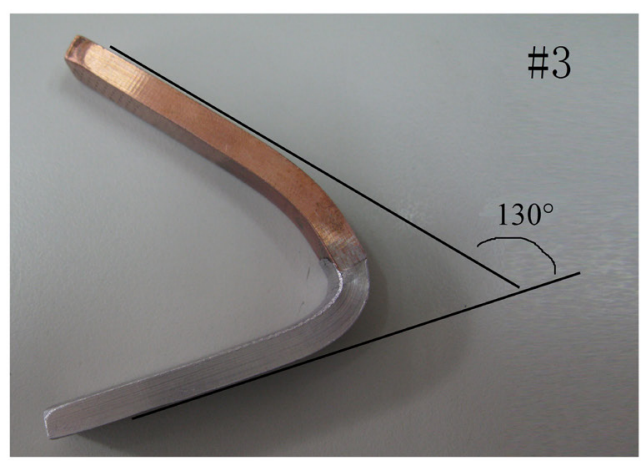

(b)

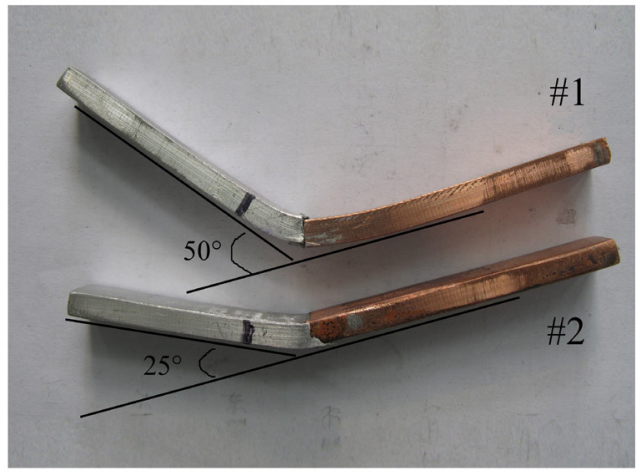

(d)

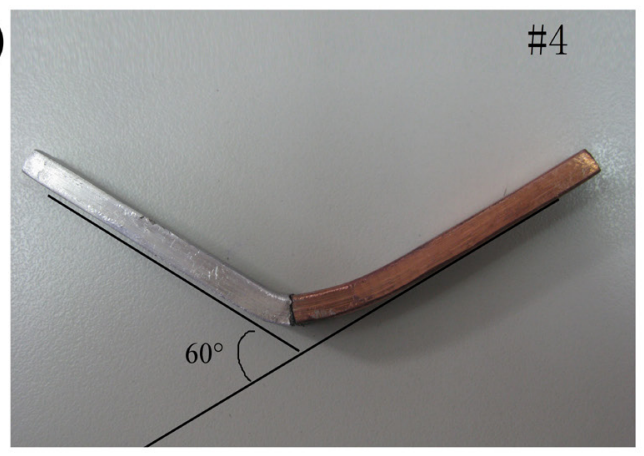

Figure 13. Mechanical test (a) tensile test of all joints; (b) bending test of these joints made with \#1 and \#2 filler foil; (c) bending test of the joint made with \#3 filler foil; (d) bending test of the joint made with \#4 filler foil. 
thin laminar IMCs layer can result in a high quality $\mathrm{Al} / \mathrm{Cu}$ joint in strength and ductility. However, both $\mathrm{Al}_{2} \mathrm{O}_{3}$ (or $\left.\mathrm{MgO}\right)$ and the non-planar interface of IMCs layer can decrease the ductility of the joint.

Figure 14 shows the bending fracture of the joints made using Al-6Si-2.5Cu-2Mg-1Ga-0.05Ce filler foil (\#2) and Al-8Si-4Cu-2.5Mg-1Ga-0.05Ce filler foil (\#4). There are some tearing ridges in the fracture surface of the two joints as shown in Figure 14b and Figure 14c. This indicates that both ductile fracture and brittle fracture occur simultaneously when bending tests are performed in the two joints. A large number of inter-granular fractures are also found in both fracture surfaces as shown in Figure 14a and Figure 14d. That is to say, both joints have low ductility because inter-granular fracture is a characteristic of brittle fracture. Moreover, cracks are observed in the fracture surface of the joint made by Al-6Si-2.5Cu-2Mg-1Ga-0.05Ce foil (\#2) and dimples are found in the fracture surface of the joint made by $\mathrm{Al}-8 \mathrm{Si}-4 \mathrm{Cu}-2.5 \mathrm{Mg}-1 \mathrm{Ga}-0.05 \mathrm{Ce}$ foil (\#4), as shown in Figure $14 \mathrm{~b}$ and Figure $14 \mathrm{~d}$, respectively. This is the reason that the ductility of the former joint (bending angle $=25^{\circ}$ ) is lower than that of the latter (bending angle $=60^{\circ}$ ).

Figure 15 shows the electrical resistivity of $\mathrm{Al} / \mathrm{Cu}$ joints made by different filler foils, the resistivity of copper and aluminum are also given. The order of electrical resistivity of all the joints induction brazed with different filler foils is $\mathrm{Cu}<\# 3<\# 2<\# 1<\# 4<\mathrm{Al}$. Based on the microstructure and electrical properties, a planar continuous IMCs layer can lead to the best conductivity, while a wavy continuous IMCs results in the lowest conductivity. Abbasi et al. ${ }^{38}$ proposed theoretical resistivity to evaluate the conductivity of $\mathrm{Al} / \mathrm{Cu}$ joint. The theoretical resistivity was decided by the volume fraction and resistivity of copper and aluminum under ignoring the existence of interfacial IMCs. In this study, the resistivity of $\mathrm{Al} / \mathrm{Cu}$ joint made using $\mathrm{Al}-8 \mathrm{Si}-4 \mathrm{Cu}-2 \mathrm{Mg}-1 \mathrm{Ga}-0.05 \mathrm{Ce}$ foil (\#3) is lower than the theoretical resistivity, showing an excellent conductivity.

\section{Discussion}

\subsection{The role of alloying elements in filler foil}

According to Al-Cu binary phase diagram, $\mathrm{Al}$ and $\mathrm{Cu}$ can form eutectic liquid phase at $548^{\circ} \mathrm{C}$. Theoretically, $\mathrm{Al}$ and $\mathrm{Cu}$ can be joined by the eutectic phase when it is cooled to room temperature. In the work by Han et al. ${ }^{39,40}$, an IMCs layer and a eutectic phase $\left(\alpha-\mathrm{Al}+\mathrm{CuAl}_{2}\right)$ were formed when copper and aluminum were hold at $550^{\circ} \mathrm{C} \sim 580^{\circ} \mathrm{C}$ for $10 \sim 25 \mathrm{~min}$. The joint was brittle due to inhomogeneous bonding by different morphologies of IMCs, such as island, dendritic and layer. In this work, Al-Si-Cu-Mg-Ga-Ce alloy was used as filler material to induction aluminum to copper and produced a high quality $\mathrm{Al} / \mathrm{Cu}$ joint. The influence of alloying elements on controlling IMCs and removing oxide film are discussed based on the results above.

$\mathrm{Al}$ is the main element in the filler foil. From the perspective of welding metallurgy, the main element of the filler metal should be the base metal element. So, $\mathrm{Al}$ and $\mathrm{Cu}$ (a)

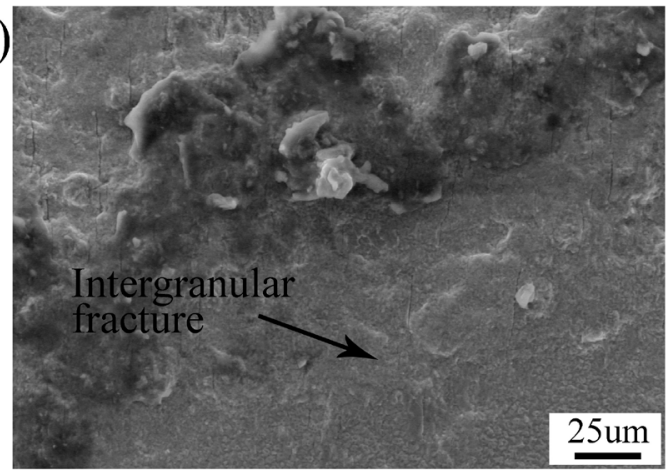

(c)

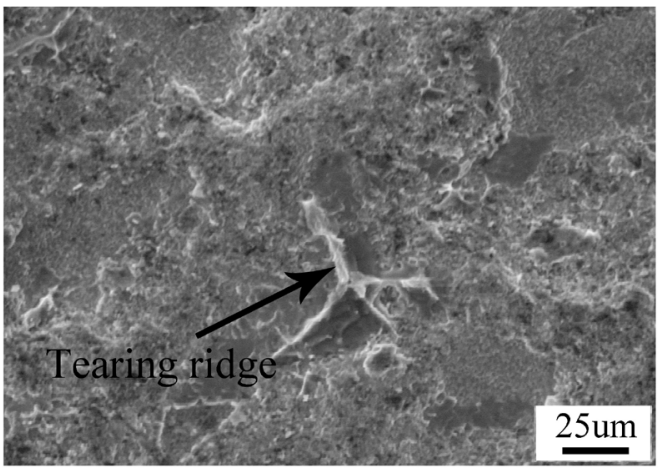

(b)

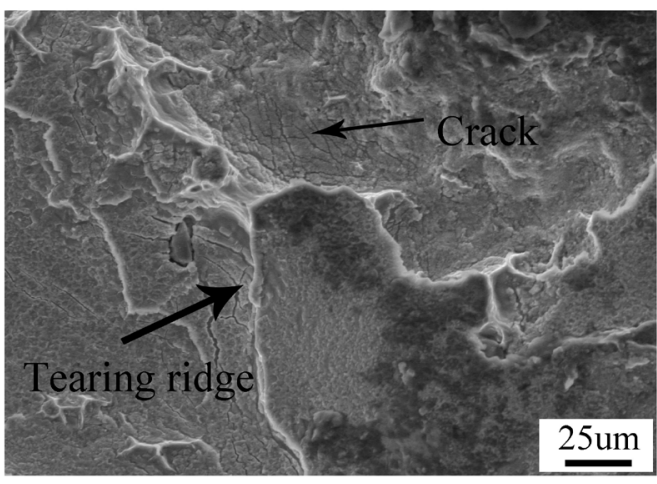

(d)

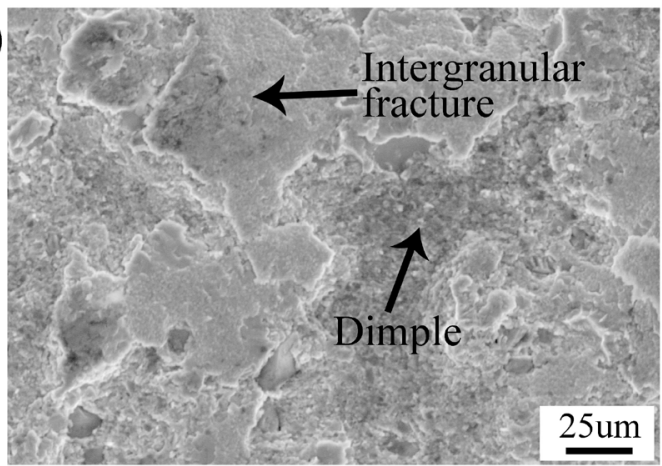

Figure 14. Bending fracture morphology of $\mathrm{Al} / \mathrm{Cu}$ joint induction brazed using $\mathrm{Al}-6 \mathrm{Si}-2.5 \mathrm{Cu}-2 \mathrm{Mg}-1 \mathrm{Ga}-0.05 \mathrm{Ce}$ foil(\#2): (a) $\mathrm{Cu}$ side, (b) Al side and Al-8Si-4Cu-2.5Mg-1Ga-0.05Ce foil(\#4) : (c) Cu side, (d) Al side. 


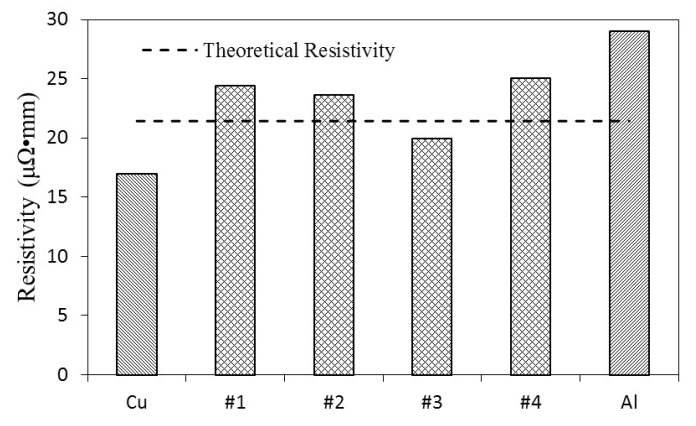

Figure 15. The electrical resistivity of induction brazed $\mathrm{Al} / \mathrm{Cu}$ joints and base metals.

can be used as main component in the filler metal. However, the melting temperature of $\mathrm{Cu}\left(1083^{\circ} \mathrm{C}\right)$ is higher than that of $\mathrm{Al}\left(660^{\circ} \mathrm{C}\right)$. An elevated brazing temperature is needed to melt the filler metal when $\mathrm{Cu}$ is used as main element in the filler metal. The higher the welding temperature, the easier it is to form IMCs. Therefore, using Al as main element is more conducive to controlling the formation of IMCs.

$\mathrm{Cu}$ atom has high diffusion ability due to its small atomic radius of $1.28 \AA^{33}$. It can diffuse into $\mathrm{Al}_{2} \mathrm{O}_{3}$ film with a few nanometers thick ${ }^{41}$. The native surface $\mathrm{Al}_{2} \mathrm{O}_{3}$ film on aluminum is about a few nanometers. Therefore, $\mathrm{Cu}$ can diffuse through the oxide film and then react with aluminum base metal. According to Al-Cu binary phase diagram, $\mathrm{Cu}$ can form an eutectic liquid( $\mathrm{Al}-33 \mathrm{Cu})$ with $\mathrm{Al}$ at $548^{\circ} \mathrm{C}$. The surface $\mathrm{Al}_{2} \mathrm{O}_{3}$ film can be disrupted by the eutectic liquid. Therefore, $\mathrm{Cu}$ in the filler foil helps to disrupt the oxide film. Theoretically, 33 mass $\%$ of the $\mathrm{Cu}$ in the filler foil can form the most eutectic phase, which is good for disrupting the oxide film. However, more $\mathrm{Cu}$ in the filler foil will form more $\mathrm{Cu}_{\mathrm{x}} \mathrm{Al}_{\mathrm{y}}{ }^{42}$. So the $\mathrm{Cu}$ content in the filler foil should be controlled within a certain range. The maximum content of copper is $5.8 \mathrm{mass} \%$ in aluminum solid solution. In this work, $2.5 \mathrm{mass} \% \sim 4 \mathrm{mass} \% \mathrm{Cu}$ has the ability to disrupt the oxide film and control IMCs.

$\mathrm{Si}$ can form a eutectic phase (Al-12Si) with $\mathrm{Al}$ at $577^{\circ} \mathrm{C}$ according to Al-Si binary phase diagram. The eutectic phase can also help to disrupt the surface oxide film. Moreover, Si atom has good compatibility with $\mathrm{Al}$ atom and $\mathrm{Cu}$ atom, which can enhance the liquid fluidity. Turriff $\mathrm{DM}^{43}$ found that the surface oxide film could not prevent the diffusion of Si when there is liquid between faying surfaces. Therefore, Si has the ability to disrupt the oxide film. Mazar Atabaki et al. ${ }^{44}$ found that $\mathrm{Si}$ in filler metal was beneficial to the partial disruption of oxide film. Further work showed that $\mathrm{Si}$ in filler materials could inhibit the formation of $\mathrm{CuAl}_{2}{ }^{31}$. Therefore, the addition of $\mathrm{Si}$ in the filler foil is beneficial to disrupt the oxide film and control $\mathrm{Cu}_{\mathrm{x}} \mathrm{Al}_{\mathrm{y}}$. In the work ${ }^{28,45,46}$, the filler material was often added with 12 mass $\% \mathrm{Si}$, which can form the most eutectic phase at a lower welding temperature, so as to control IMCs. In this study, Al-Si-Cu-Mg-Ga-Ce multi-element alloy was used as filler alloy. The Si content in the filler alloy was relatively high, ranging from 6 mass $\% \sim 8$ mass $\%$. The high content of silicon in the filler alloy can improve the wettability of the liquid filler alloy to copper and aluminum solid substrate. According to the Al-Cu-Si ternary phase diagram, 6 mass $\% \mathrm{Si}$ can form a ternary eutectic liquid phase at $524^{\circ} \mathrm{C}$. The liquid filler alloy can fully fill the welding area at welding temperature $\left(590^{\circ} \mathrm{C} \sim 600^{\circ} \mathrm{C}\right)$ and then increase the diffusion path between copper and aluminum. Since $\mathrm{Si}$ has good compatibility with copper and aluminum. Si can diffuse into both copper and aluminum base metals and avoid the formation of Si-containing phases in the joint. Therefore, $\mathrm{Si}$ in the filler alloy was beneficial to avoid the presence of Si-containing phases, and only $\mathrm{Cu}_{\mathrm{x}} \mathrm{Al}_{\mathrm{y}}$ phases appeared in the joint, as shown in Figure 16a. In addition, $\mathrm{Al}$ and $\mathrm{Cu}$ was induction brazed by the inter-diffusion of copper and aluminum. Some $\mathrm{Cu}_{\mathrm{x}} \mathrm{Al}_{\mathrm{y}}$ phases were formed when copper and aluminum diffused to a certain concentration in the joint area. The characteristics of the $\mathrm{Cu}_{\mathrm{x}} \mathrm{Al}_{\mathrm{y}}$ phase determined the welding of $\mathrm{Cu}$ and $\mathrm{Al}$. Si diffused towards the copper and aluminum on both sides, but more towards the copper side during induction brazing, as shown in Figure 16b d. Si decreased the inter-diffusion between copper and aluminum, especially the diffusion of copper to the aluminum side, thereby suppressing the formation of the $\mathrm{Cu}_{\mathrm{x}} \mathrm{Al}_{\mathrm{y}}$ phases.

$\mathrm{Mg}$ atom can react with $\mathrm{Al}_{2} \mathrm{O}_{3}$ to decompose the alumina. The possible chemical reactions are shown as Equation 1 and Equation 2. Many works have shown that the chemical reactions depend on $\mathrm{Mg}$ content and welding temperature. In the work ${ }^{37}, \mathrm{Mg}$ reacted with $\mathrm{Al}_{2} \mathrm{O}_{3}$ to form $\mathrm{MgAl}_{2} \mathrm{O}_{4}$ according to Equation 1 when $\mathrm{Mg}$ content is about $0.1 \sim 1.0$ mass $\%$. Further work showed that the alumina was removed according to Equation 1 when $\mathrm{Mg}$ content was 0.3 mass $\%$ and according to Equation 2 when $\mathrm{Mg}$ content was $2.5 \mathrm{mass} \%$ at the temperature of $350^{\circ} \mathrm{C} \sim 600^{\circ} \mathrm{C}^{47}$. In this study, $\mathrm{MgO}$ is measured in the joint, showing that the surface oxide film was decomposed according to Equation 2. When there is no $\mathrm{Mg}$ in the filler foil, the $\mathrm{Al}_{2} \mathrm{O}_{3}$ will stay in the final joint. When $\mathrm{Mg}$ content is $2 \mathrm{mass} \%$, the surface $\mathrm{Al}_{2} \mathrm{O}_{3}$ film is decomposed to small $\mathrm{MgO}$ particles. However, $2.5 \mathrm{mass} \%$ $\mathrm{Mg}$ in the filler foil changes the interface morphology of $\mathrm{CuAl}_{2}$ from planar to non-planar. The reason may be that excess $\mathrm{Mg}$ disrupts the equilibrium state of liquid near aluminum side and then leads to some rough nucleation for $\mathrm{CuAl}_{2}$. Overall, $\mathrm{Mg}$ can decompose the oxide film and change the interface morphology of IMCs.

$3 \mathrm{Mg}+4 \mathrm{Al}_{2} \mathrm{O}_{3}=3 \mathrm{MgAl}_{2} \mathrm{O}_{4}+2 \mathrm{Al}$

$3 \mathrm{Mg}+\mathrm{Al}_{2} \mathrm{O}_{3}=2 \mathrm{Al}+3 \mathrm{MgO}$

Gallium can form a eutectic liquid phase (Al-99Ga) with aluminum at $26.6^{\circ} \mathrm{C}$. The eutectic phase can remove surface oxide film and enhance the bonding of aluminum. Bhadeshia ${ }^{48}$ and Mahmoudi Ghaznavi et al. ${ }^{49}$ have reported that gallium can be used as filler metal to flux-free braze pure aluminum and transient liquid phase diffusion bonding of aluminum alloy. However, gallium will segregate in the aluminum grain boundaries, leading to brittleness. Therefore, there are some restrictions when using gallium as filler metal, such as low welding temperature, short welding time and controllable dosage. In this study, gallium is added into the aluminum alloy filler foil to disrupt the oxide film during induction brazing. Meantime, the content of gallium in filler foil is $1 \mathrm{mass} \%$ to avoid the detrimental effect of liquid gallium 
(a)

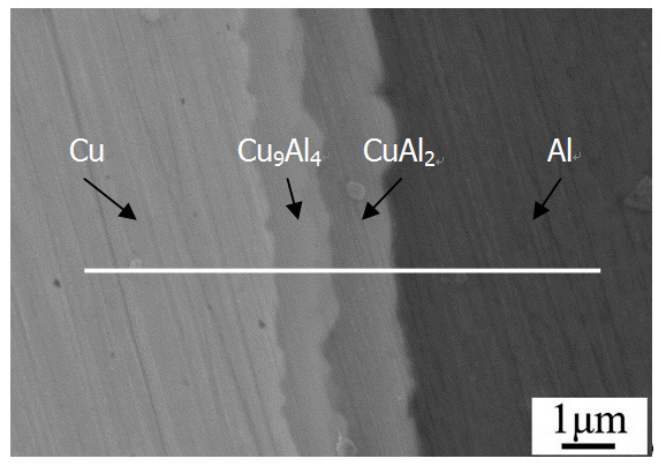

\section{(c)}

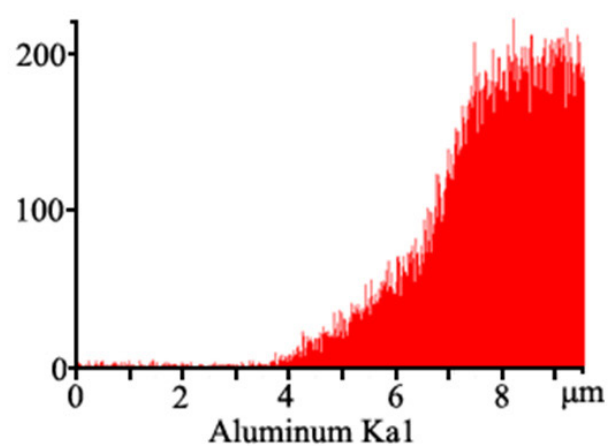

(b)

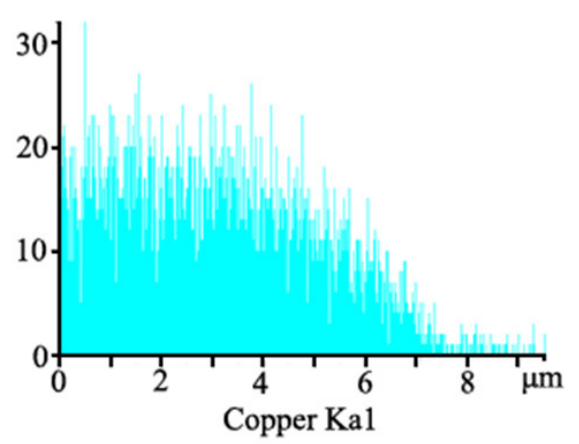

(d)

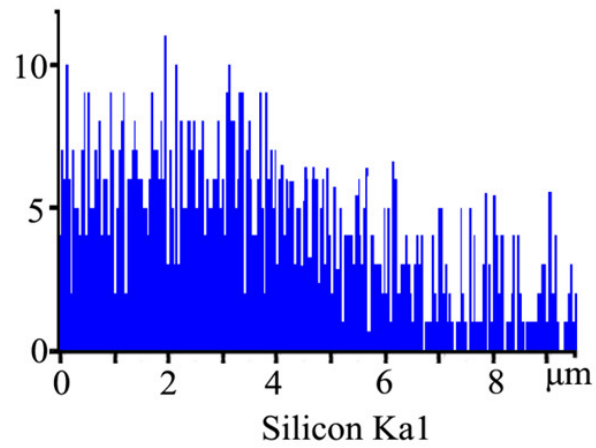

Figure 16. SEM and EDS line analysis of $\mathrm{Al} / \mathrm{Cu}$ joint made using $\mathrm{Al}-8 \mathrm{Si}-4 \mathrm{Cu}-2 \mathrm{Mg}-1 \mathrm{Ga}-0.05 \mathrm{Ce}$ filler foil (a) high magnified joint microstructure; (b) line distribution of $\mathrm{Cu}$; (c) line distribution of $\mathrm{Al}$; (d) line distribution of Si.

on the aluminum by minimizing its dosage. In addition, solid state foil is easier to handle than liquid gallium for brazing.

Rear earth elements can segregate at grain boundary and then change the formation mechanism of $\mathrm{Al}_{2} \mathrm{O}_{3}$ at high temperature, such as $\mathrm{Y}, \mathrm{Ce}, \mathrm{La}$ and $\mathrm{Hf}$. Ji $\mathrm{F}^{50}$ found that $0.03 \sim 0.05 \mathrm{mass} \% \mathrm{Ce}$ in $\mathrm{Zn}$-Al-Ce filler metal can decrease the grain size of filler metal and improve its wettability on aluminum base metal. In this study, $0.05 \mathrm{mass} \% \mathrm{Ce}$ is used to improve the wettability of filler metal and then enhance induction brazing.

Different from the existing $\mathrm{Zn}-\mathrm{Al}$ and Al-Si filler metal, a multi-element alloy of Al-Si-Cu-Mg-Ga-Ce is developed as filler foil to disrupt oxide film and control IMCs in this study. Chang ${ }^{51}$ calculated liquidus projections of $\mathrm{Al}-\mathrm{Cu}-\mathrm{Mg}$ $\mathrm{Si}$ in the $\mathrm{Al}$ corner, as shown in Figure 17. There are three quaternary eutectic point, which are $\mathrm{Al}-27.2 \mathrm{Cu}-2.7 \mathrm{Mg}-5.3 \mathrm{Si}$ at $\mathrm{I}_{1}, \mathrm{Al}-32.9 \mathrm{Cu}-7 \mathrm{Mg}-0.6 \mathrm{Si}$ at $\mathrm{I}_{2}, \mathrm{Al}-1.2 \mathrm{Cu}-34 \mathrm{Mg}-0.1 \mathrm{Si}$ at $\mathrm{I}_{3}$, as shown in Equation 3, 4 and 5, respectively. It can be found that some intermetallic compounds are formed when the liquid Al-Cu-Si-Mg is cooled to a solid state, such as $\mathrm{CuAl}_{2}$, $\mathrm{Al}_{5} \mathrm{Cu}_{2} \mathrm{Mg}_{2} \mathrm{Si}_{6}, \mathrm{Mg}_{2} \mathrm{Si}, \mathrm{Al}_{2} \mathrm{CuMg}$ and $(\mathrm{Al}, \mathrm{Cu})_{49} \mathrm{Mg}_{32}$. These intermetallic compounds are harmful to the ductility. In this work, the induction brazing temperature is $590^{\circ} \mathrm{C} \sim 600^{\circ} \mathrm{C}$, which is higher than the quaternary eutectic temperature of $448^{\circ} \mathrm{C} \sim 509^{\circ} \mathrm{C}$. Therefore, these intermetallic compounds can be avoided at the brazing temperature. In other words, the multi-element alloy filler foil can control IMCs by matching the elements at high brazing temperature.

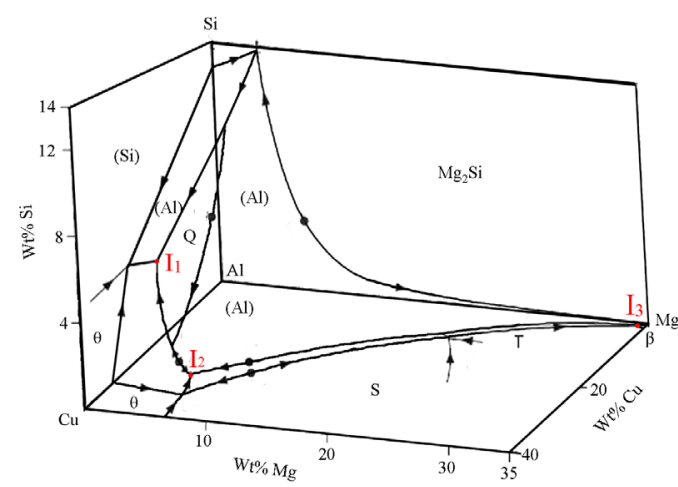

Figure 17. Calculated liquidus projections of $\mathrm{Al}-\mathrm{Cu}-\mathrm{Mg}-\mathrm{Si}$ in the Al corner.

$\mathrm{I}_{1}: 509^{\circ} \mathrm{C} L=(\mathrm{Al})+\mathrm{CuAl} \mathrm{l}_{2}+(\mathrm{Si})+\mathrm{Al}_{5} \mathrm{Cu}_{2} \mathrm{Mg}_{2} \mathrm{Si}_{6}$

$\mathrm{I}_{2}: 502^{\circ} \mathrm{C} \mathrm{L}=(\mathrm{Al})+\mathrm{CuAl}_{2}+\mathrm{Mg}_{2} \mathrm{Si}+\mathrm{Al}_{2} \mathrm{CuMg}$

$\mathrm{I}_{3}: 448^{\circ} \mathrm{C} L=(A l)+A l_{3} M g_{2}+M g_{2} S i+(A l, C u)_{49} M g_{32}$

\subsection{Mechanism of Al/Cu induction brazing}

Brazing is a common welding method to join copper and aluminum. Usually, a flux is applied to remove the surface oxide film before brazing, such as $\mathrm{AlF}_{3}-\mathrm{CsF}$. Then, a filler 
(a)

Temperature

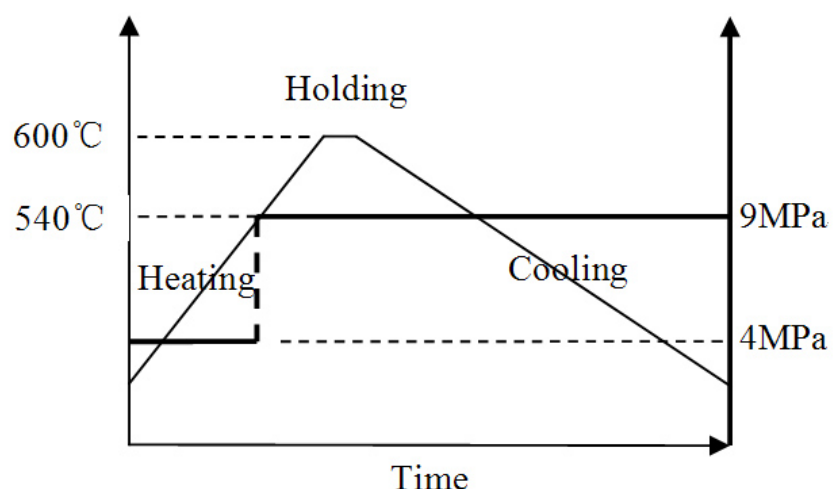

(b)

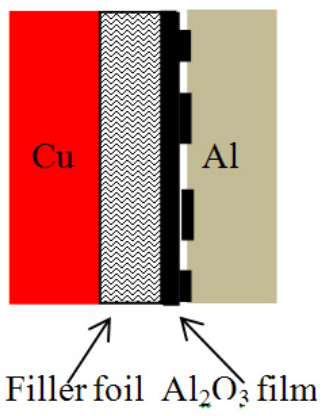

(e)
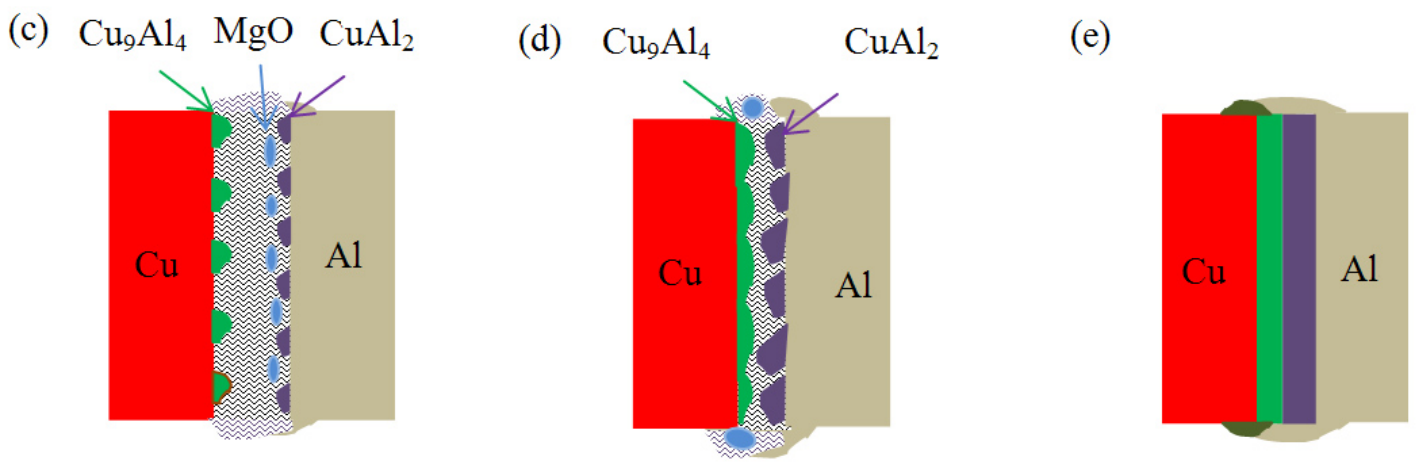

Figure 18. Mechanism of $\mathrm{Al} / \mathrm{Cu}$ induction brazing (a) induction brazing process curve; (b) solid state reaction during heating stage; (c) liquid state reaction after the filler foil is melted during heating stage; (d) liquid state reaction during holding stage; (e) final joint during cooling stage.

metal is used to form the joint without brazing pressure, such as $\mathrm{Zn}-\mathrm{Al}$, Al-Si. The brazed joint is composed of brazing seam and interface layer. The brazing seam is often a eutectic phase related with the filler metal, and the interface layer is IMCs. Both interfacial IMCs and brazing seam can affect the joint properties. For example, the brazing seam can decrease the joint ductility. Moreover, the residual corrosive flux will adversely affect the joint properties. Therefore, many researches have been devoted to design the filler metal and fluxes to achieve a high quality joint. In this study, a novel filler metal is developed to induction braze aluminum and copper under brazing pressure. Unlike conventional brazing, induction brazing joint consists of a thin IMCs layer, which has integral properties in term of strength, ductility and conductivity. The mechanism of $\mathrm{Al} / \mathrm{Cu}$ induction brazing is shown in Figure 18. Induction brazing process includes three stages of heating, holding and cooling. A brazing pressure, $4 \mathrm{MPa}$ before the filler foil melted and 9MPa after the filler foil melted, is applied during induction brazing, as shown in Figure 18a.

In heating stage from room temperature to the melting point of filler foil, solid-state induction happens among filler foil, copper and aluminum. The surface $\mathrm{Al}_{2} \mathrm{O}_{3}$ film starts to detach from aluminum base metal due to the chemical reaction by filler foil, as shown in Figure 18b. Because the solid-state diffusion rate is low, the filler foil has no significant effect on the removal of surface oxide film. When the filler foil is heated to melt, the liquid filler foil will wet both surfaces of copper and aluminum. Three reactions will happen between copper and aluminum. At copper/liquid filler foil, Al atom in filler foil will diffuse into copper base metal due to the large diffusion coefficient in liquid. Copper solid solution will form firstly and then $\mathrm{Cu}_{9} \mathrm{Al}_{4}$ when more and more $\mathrm{Al}$ diffuses into $\mathrm{Cu}$ solid solution. On the aluminum side, liquid filler foil will permeate the crevice between $\mathrm{Al}_{2} \mathrm{O}_{3}$ film and aluminum base metal. Meanwhile, $\mathrm{Al}_{2} \mathrm{O}_{3}$ will be changed to $\mathrm{MgO}$ by the chemical reaction with $\mathrm{Mg}$ in liquid filler foil. At liquid/aluminum interface, $\mathrm{Cu}$ will diffuse into aluminum base metal and forms aluminum solid solution and then $\mathrm{CuAl}_{2}$. Moreover, some liquid will be expelled to the edge by the increased pressure. The movement of liquid will disrupt the oxide film. In this stage, small $\mathrm{Cu}_{9} \mathrm{Al}_{4}$ and $\mathrm{CuAl}_{2}$ will segregate on the copper and aluminum, respectively, as shown in Figure 18c.

In holding stage, both $\mathrm{Cu}_{9} \mathrm{Al}_{4}$ and $\mathrm{CuAl}_{2}$ will grow up with inter-diffusion between copper and aluminum. $\mathrm{Cu}_{9} \mathrm{Al}_{4}$ will firstly become continuous on copper side. Some $\mathrm{CuAl}_{2}$ and $\mathrm{MgO}$ particles will be expelled to the edge by the flow of liquid. Meantime, a eutectic liquid phase will be formed at the temperature above $548.2^{\circ} \mathrm{C}$. The eutectic liquid will also accelerate the diffusion of copper and aluminum and enhance the growth of IMCs. These two IMCs will become thick 
and other new IMCs will form if there are too much liquid resulted from long time holding. Therefore, the thickness of IMCs can be controlled by adjusting the thickness of filler foil and the holding time. In addition, the aluminum base metal near faying surface will be extruded partly by the brazing pressure for its low high temperature strength as shown in Figure 18d. The extrusion of aluminum can stop the faying surface from oxidation.

In cooling stage, the liquid on the edge will solidify. Both $\mathrm{Cu}_{9} \mathrm{Al}_{4}$ and $\mathrm{CuAl}_{2}$ will grow up and become continuous thin layer as shown in Figure 18e. Under high cooling condition with argon flux, no solid-state phase transformation occurs as both $\mathrm{Cu}$ and $\mathrm{Al}$ have low diffusion rate in solid $\mathrm{Cu}_{9} \mathrm{Al}_{4}$ and $\mathrm{CuAl}_{2}$ layer. So, no other IMCs are formed in this stage.

Different from brazing, the filler metal of induction brazing can fully diffuse into base metals in short induction brazing time. There is no braze seam in the joint, only a thin interface layer.

\subsection{Relationship between joint properties and interfacial IMCs layer}

From the viewpoint of welding metallurgy, an ideal $\mathrm{Al} / \mathrm{Cu}$ dissimilar joint should be a solid solution and free of IMCs. However, it is difficult to prevent the formation of IMCs during welding due to the high affinity of copper and aluminum. The thickness and morphology of IMCs have great impact on the joint properties. In the work ${ }^{52}$, the strength, ductility and conductivity of friction welded $\mathrm{Al} / \mathrm{Cu}$ joints were reduced when the thickness of interfacial $\mathrm{Cu}_{x} \mathrm{Al}_{y}$ was increased. Many investigations have shown that the thickness of IMCs should be less than $2 \sim 5 \mu \mathrm{m}^{53}$. In this paper, the thickness of interfacial IMCs is $2 \sim 3 \mu \mathrm{m}$, and all joints have high tensile strength equivalent to that of aluminum base metal. However, all joints have different morphologies, and their ductility and conductivity are different. There are controversial opinions on the impact of IMCs morphologies on joint performance. Some research found that the continuous IMCs layer can enhance the metallurgical bonding and then increase the joint strength and ductility ${ }^{1,2,54}$. However, other research found that discontinuous IMCs can increase the joint strength and ductility ${ }^{3,31}$. On the other hand, some investigations found that a planar IMCs layer can increase the conductivity, the strength and ductility of the joints ${ }^{4,5}$. However, other investigations thought that the wavy IMCs was good for metallurgical bonding ${ }^{6,7}$.

Based on the welding of aluminum to copper, there are three phase structures in the joint, such as IMCs, oxides and solid solution. The morphology of IMCs can be described using contact radius ( $\mathrm{r}$ ) and spacing $(\lambda)$. The planar IMCs can be obtained when $r \rightarrow \infty$ and the continuous IMCs can be obtained when $\lambda=0$.

In multiphase alloy, second phase particles will prevent the movement of dislocation and then increase the strength. The strengthening effect can be expressed by Equation 6 .

$\tau=\frac{\mathrm{G} \times \mathrm{b}}{\lambda}$

where $\tau$ is shear stress driving the movement of dislocation, $G$ is shear elastic modulus of second phase, $b$ is burgers vector of dislocation, $\lambda$ is spacing between second phase particles.
For continuous IMCs in $\mathrm{Al} / \mathrm{Cu}$ joint, $\lambda=0$. So, $\tau \rightarrow \infty$. That is to say, the continuous IMCs can increase greatly the joint strength. As shown in Figure 5 and Figure 13, the bending strength of the joints with continuous interfacial layers (\#3 and \#4) are higher than that of the joints with discontinuous interfacial layers (\#1 and \#2). Comparing Figure 5c and Figure 5d, Figure 13c and Figure 13d, it was found that the two joints (\#3 and \#4) had the same thickness of IMCs layer and the same phase type of IMCs. However, the ductility of the two joints was different with the different interfacial morphologies of $\mathrm{CuAl}_{2}$. The bending angle of the joint (\#4) with non-planar interface $\mathrm{CuAl}_{2}$ was lower than that of the joint (\#3) with planar interface $\mathrm{CuAl}_{2}$, indicating the non-planar interface of IMCs layer with the same thickness and phase type decreases the ductility of the joint. It is well known that the hardness of $\mathrm{CuAl}_{2}$ is much higher than that of copper and aluminum. The hard $\mathrm{CuAl}_{2}$ becomes a brittle point in the $\mathrm{CuAl}_{2} / \mathrm{Al}$ structure. The more $\mathrm{CuAl}_{2}$, the lower the joint ductility. The contact area between non-planar interface $\mathrm{CuAl}_{2}$ and aluminum was more than that between planar interface $\mathrm{CuAl}_{2}$ and aluminum. The ductility of the joint was then decreased due to more $\mathrm{CuAl}_{2} / \mathrm{Al}$ contact points resulted from non-planar interface $\mathrm{CuAl}_{2}$. For discontinuous IMCs in $\mathrm{Al} / \mathrm{Cu}$ joint, $\lambda \neq 0$. So, the strengthening effect depends on IMCs, oxides and solid solution, as expressed by Equation 7.

$$
\tau=\left(\frac{G_{I M C}}{I M c}+\frac{G_{\text {oxide }}}{\text { oxide }}+\frac{G_{s l}}{s l}\right) \times \mathrm{b}
$$

where $\mathrm{G}_{\mathrm{IMC}}, \mathrm{G}_{\text {oxide }}$ and $\mathrm{G}_{\mathrm{sl}}$ are shear elastic modulus of IMCs, oxide and solid solution, respectively. $\lambda_{\mathrm{IMC}}, \lambda_{\text {oxide }}$ and $\lambda_{\mathrm{sl}}$ are spacing between IMCs, oxides and solid solution, respectively.

Since the different contents and sizes of IMCs, oxides and solid solution can lead to different values of $\lambda$, discontinuous IMCs maybe increase the joint strength by matching the oxides and solid solutions. On the other hand, the resistance of $\mathrm{Al} / \mathrm{Cu}$ joint is a sum of a resistance of copper $\left(\mathrm{R}_{\mathrm{Cu}}\right)$, a resistance of aluminum $\left(\mathrm{R}_{\mathrm{Al}}\right)$, a resistance of second phase $\left(\mathrm{R}_{\mathrm{sp}}\right)$ and a contact resistance $\left(\mathrm{R}_{\mathrm{c}}\right)$, as expressed by Equation 8 . The metal to metal contact resistance $\left(\mathrm{R}_{\mathrm{c}}\right)$ can be expressed by Equation $9^{53}$.

$$
\begin{aligned}
& \mathrm{R}=\mathrm{R}_{\mathrm{Cu}}+\mathrm{R}_{\mathrm{Al}}+\mathrm{R}_{\mathrm{sp}}+\mathrm{R}_{\mathrm{c}} \\
& \mathrm{R}_{\mathrm{c}}=\frac{\rho}{\mathrm{L}}
\end{aligned}
$$

where $\rho$ is resistivity of metal, $\mathrm{L}$ is contact length between metals. For continuous IMCs in $\mathrm{Al} / \mathrm{Cu}$ joint, $\mathrm{R}_{\mathrm{sp}}$ is the resistance of IMCs.

Then, the contact morphology between IMCs and base metals determines the contact resistance $\mathrm{R}_{\mathrm{c}}$. As the resistivity of IMCs is higher than that of base metals, more IMCs in the interface will reduce the contact length (L) between copper and aluminum. Compared with wavy IMCs, the planar IMCs can increase the contact length between copper and aluminum and then decrease $R_{c}$. The total joint resistance $R$ is then reduced by the planar continuous IMCs. Figure 15 also showed that the resistance of the joint with wavy continuous IMCs layer is lower than that of the joint with planar continuous IMCs layer. For discontinuous IMCs in $\mathrm{Al} / \mathrm{Cu}$ joint, $\mathrm{R}_{\mathrm{sp}}$ is 
a sum of resistance of IMCs $\left(\mathrm{R}_{\mathrm{IMC}}\right)$, oxides $\left(\mathrm{R}_{\text {oxide }}\right)$ and solid solution $\left(\mathrm{R}_{\mathrm{s}}\right)$. It can be expressed by Equation 10 . According to Ohm's law, the resistance of second phases is related to their resistivity and volume. The resistivity order of these three second phases are $\rho_{\text {oxide }}>\rho_{\text {IMC }}>\rho_{\text {sl }}$. Compared with single IMCs, oxide and solid solution may be increase or decrease the $\mathrm{R}_{\mathrm{sp}}$, which depends on their volume. Therefore, discontinuous IMCs can increase the joint conductivity by matching the oxides and solid solutions.

$$
\frac{1}{\mathrm{R}_{\mathrm{sp}}}=\frac{1}{\mathrm{R}_{\mathrm{IMC}}}+\frac{1}{\mathrm{R}_{\text {oxide }}}+\frac{1}{\mathrm{R}_{\mathrm{sl}}}
$$

As discussed above, the planar continuous IMCs can increase the strength, ductility and conductivity of the $\mathrm{Al} / \mathrm{Cu}$ joint. Moreover, the discontinuous IMCs can also have a beneficial effect on joint performance by controlling the content of various second phases in the joint.

\section{Conclusion}

In this article, four types of Al-(6 8)Si-(2.5 4) Cu-(0 2.5) $\mathrm{Mg}-1 \mathrm{Ga}-0.05 \mathrm{Ce}$ were designed to induction braze copper and aluminum in air. The influence of $\mathrm{Mg}$, $\mathrm{Si}$ and $\mathrm{Cu}$ in the filler foil on induction brazing behavior was investigated and the main conclusions are drawn below.

1. The Al-Si-Cu-Mg-Ga-Ce foils can fully diffuse into base metals in short induction brazing time. There is only a thin interfacial layer in the joint and free from eutectic phase.

2. $\mathrm{Mg}$ in the filler foils can convert the native $\mathrm{Al}_{2} \mathrm{O}_{3}$ film into $\mathrm{MgO}$. It is helpful to stop the re-oxidation of aluminum base metal in non-vacuum induction brazing. However, excessive $\mathrm{Mg}$ will change the interface morphology of IMCs from planar to nonplanar. $\mathrm{Cu}$ and $\mathrm{Si}$ in the filler foil are beneficial to clear the oxide film, and a suitable amount of $\mathrm{Cu}$ and $\mathrm{Si}$ can fully remove residual oxide film and result in a thin IMCs layer.

3. A thin planar IMCs layer can result in a high quality $\mathrm{Al} / \mathrm{Cu}$ joint in strength, ductility and conductivity. However, residual oxide and the non-planar interface of IMCs layer can decrease the ductility of the joint. Al-8Si-4Cu-2Mg-1Ga-0.05Ce filler foil can produce an excellent induction brazed joint in argon flux instead of vacuum. The joint consists of a $2 \mu \mathrm{m}$ $\mathrm{Cu}_{9} \mathrm{Al}_{4} / \mathrm{CuAl}_{2}$ planar layer and free from oxide film. The strength, ductility and conductivity of the joint are optimally matched. The tensile strength of the joint is higher than that of aluminum base metal. The bend angle is higher $130^{\circ}$, showing high ductility. The electrical resistivity of the joint is lower than the theoretical value, showing excellent electrical conductivity.

\section{Acknowledgements}

This work was supported by Shandong Jianzhu University [No.X18063Z] and State Grid Corporation of China [No. SGKJ[2010]14].

\section{References}

1. Li G, Zhou L, Zhou W, Song X, Huang Y. Influence of dwell time on microstructure evolution and mechanical properties of dissimilar friction stir spot welded aluminum-copper metals. $\mathrm{J}$ Mater Res Technol. 2019;8(3):2613-24.

2. Li GH, Zhou L, Shu FY, Liu YC. Statistical and metallurgical analysis of dissimilar friction stir spot welded aluminum/copper metals. J Mater Eng Perform. 2020;29(3):1830-40.

3. Mathivanan K, Plapper P. Laser welding of dissimilar copper and aluminum sheets by shaping the laser pulses. Procedia Manuf. 2019;36:154-62.

4. Shafiei A, Yerevanian V, Maijer DM. Effect of weld parameters on the microstructure of aluminum-copper joints produced by flash welding. J Mater Eng Perform. 2020;29(8):5214-26.

5. Anbukkarasi R, Kailas SV. Influences of shape of the new interfaces and morphology of the intermetallics on mechanical properties of aluminum AA2024-pure copper joints by friction stir welding. Int J Adv Manuf Technol. 2020;106(11-12):5071-83.

6. Ayaz M, Khandaei M, Vahidshad Y. Evaluating the electromagnetic welding parameters for improving the mechanical properties of Al-Cu joint. Arab J Sci Eng. 2020;45(11):9619-37.

7. Dhara S, Das A. Impact of ultrasonic welding on multi-layered Al-Cu joint for electric vehicle battery applications: a layer-wise microstructural analysis. Mater Sci Eng A. 2020;791:139795.

8. Li MS, Zhang C, Wang DY, Zhou L, Wellmann D, Tian YT. Friction stir spot welding of aluminum and copper: a review. Materials. 2020;13(1):156.

9. Yang YF, Chen HT, Li MY. Dissimilar copper-aluminum joint processed by low temperature nickel electroplating. J Mater Process Technol. 2017;242:68-76.

10. Xiong JT, Peng Y, Zhang H, Li JL, Zhang FS. Microstructure and mechanical properties of Al-Cu joints diffusion bonded with Ni or Ag interlayer. Vacuum. 2018;147:187-93.

11. Sahu PK, Pal S, Pal SK. Al/Cu Dissimilar friction stir welding with $\mathrm{Ni}, \mathrm{Ti}$, and $\mathrm{Zn}$ foil as the interlayer for flow control, enhancing mechanical and metallurgical properties. Metall Mater Trans, A Phys Metall Mater Sci. 2017;48A(7):3300-17.

12. Zhang GF, Su W, Zhang JX, Wei ZX. Friction stir brazing: a novel process for fabricating $\mathrm{Al} / \mathrm{Steel}$ layered composite and for dissimilar joining of Al to steel. Metall Mater Trans, A Phys Metall Mater Sci. 2011;42A(9):2850-61.

13. Zhang GF, Zhang K, Zhang LJ, Zhang JX. Approach to disrupting thick intermetallic compound interfacial layer in friction stir brazing (FSB) of $\mathrm{Al} / \mathrm{Cu}$ plates. Sci Technol Weld Join. 2014;19(7):554-9.

14. Boucherit A, Avettand-Fènoël MN, Taillard R. Effect of a $\mathrm{Zn}$ interlayer on dissimilar FSSW of $\mathrm{Al}$ and $\mathrm{Cu}$. Mater Des. 2017;124:87-99.

15. Boucherit A, Abdi S, Aissani M, Mehdi B, Abib K, Badji R. Weldability, microstructure, and residual stress in $\mathrm{Al} / \mathrm{Cu}$ and $\mathrm{Cu} / \mathrm{Al}$ friction stir spot weld joints with $\mathrm{Zn}$ interlayer. Int J Adv Manuf Technol. 2020;111(5-6):1-17.

16. Gao PQ, Zhang Y, Mehta KP. Metallurgical and mechanical properties of Al-Cu joint by friction stir spot welding and modified friction stir clinching. Met Mater Int. 2020;27(8):3085-94.

17. Balasundaram R, Patel VK, Bhole SD, Chen DL. Effect of zinc interlayer on ultrasonic spot welded aluminum to copper joints. Mater Sci Eng A. 2014;607:277-86.

18. Zhang J, Wang BH, Chen GH, Wang RM, Miao CH, Zheng $\mathrm{ZX}$, et al. Formation and growth of $\mathrm{Cu}-\mathrm{Al}$ IMCs and their effect on electrical property of electroplated $\mathrm{Cu} / \mathrm{Al}$ laminar composites. Trans Nonferrous Met Soc China. 2016;26(12):3283-91.

19. Liu T, Wang QD, Sui YD, Wang QG, Ding WJ. An investigation into interface formation and mechanical properties of aluminumcopper bimetal by squeeze casting. Mater Des. 2016;89:1137-46.

20. Chen SJ, Wang D, Pu J, Zhang JQ, Liu B, Li RF. A study on the microstructure and properties of $\mathrm{Al} / \mathrm{Cu}$ lap joints welded 
by friction stir brazing with ultrahigh rotation speed. Int J Mod Phys B. 2020;33(01n03):2040053.

21. Ye Z, Huang JH, Yang WJ, Yang H, Yang J, Chen SH. Corrosion behaviors in the brazed seam of $\mathrm{Al} / \mathrm{Cu}$ dissimilar joints brazed by Zn-Al alloys. Weld World. 2020;64(6):1023-31.

22. Huang JL, Long WM, Zhong SJ. Effect of Al element in Zn$\mathrm{Al}$ fillers on the corrosion resistance of $\mathrm{Cu} / \mathrm{Al}$ brazed joints. $\mathrm{J}$ Mech Sci Technol. 2020;34(2):711-7.

23. Zhang M. Effects of interfacial reactions on microstructures and mechanical properties of $3003 \mathrm{Al} / \mathrm{T} 2 \mathrm{Cu}$ and $1035 \mathrm{Al} / \mathrm{T} 2$ $\mathrm{Cu}$ brazed joints. Crystals. 2020;10(4):248.

24. Ye Z, Huang JH, Yang H, Liu T, Yang J, Chen SH. Effect of $\mathrm{Si}$ addition on corrosion behaviors of $\mathrm{Cu} / \mathrm{Al}$ dissimilar joint brazed with novel Zn-Al-xSi filler metals. J Mater Res Technol. 2019;8(6):5171-9.

25. Liang Y, Pan JR, Zhang H, Huang P, Wang J, Shi YX, et al. Ultrasonic-assisted semi-solid forming method and microstructure evolution of aluminum/copper brazed joints. Metal. 2020;10(2):223.

26. Feng J, Songbai X, Wei D. Effects of Ti on the brazability of $\mathrm{Zn}-22 \mathrm{Al}-\mathrm{xTi}$ filler metals as well as properties of $\mathrm{Cu} / \mathrm{Al}$ brazing joints. Rare Met Mater Eng. 2013;42(12):2453-7.

27. Feng J, Xue S. Growth behaviors of intermetallic compound layers in $\mathrm{Cu} / \mathrm{Al}$ joints brazed with $\mathrm{Zn}-22 \mathrm{Al}$ and $\mathrm{Zn}-22 \mathrm{Al}-0.05 \mathrm{Ce}$ filler metals. Mater Des. 2013;51:907-15.

28. Weigl M, Albert F, Schmidt M. Enhancing the ductility of laser-welded copper-aluminum connections by using adapted filler materials. Phys Procedia. 2011;12:332-40.

29. Li G, Song JF, Lu XF, Zhu XL, Xu SY, Guo YP. Investigation on microstructure and mechanical properties of $\mathrm{Al} / \mathrm{Cu}$ butt joints by CMT method in asymmetrical V-groove configuration. Metall Res Technol. 2020;117(3):303.

30. Zhang HM, Shi Y, Gu YF, Li CK. Effect of different filler wires on mechanical property and conductivity of aluminum-copper joints. Materials. 2020;13(16):3648.

31. Wei YN, Sun F, Tan SY, Liang SH. Study on microstructure and performance of transient liquid phase bonding of $\mathrm{Cu} / \mathrm{Al}$ with Al-based interlayers. Vacuum. 2018;154:18-24.

32. Wang XG, Yuan XD, Li JN, Li XG. Influence of interfacial inter-metallic compounds on the electrical characterization of $\mathrm{Cu} / \mathrm{Al}$ joints produced by flash welding and diffusion brazing. Mater Res. 2020;23(5):e20200325.

33. Xu H, Liu C, Silberschmidt VV, Pramana SS, White TJ, Chen $\mathrm{Z}$, et al. Behavior of aluminum oxide, intermetallics and voids in $\mathrm{Cu}-\mathrm{Al}$ wire bonds. Acta Mater. 2011;59(14):5661-73.

34. Sheng LY, Yang F, Xi TF, Lai C, Ye HQ. Influence of heat treatment on interface of $\mathrm{Cu} / \mathrm{Al}$ bimetal composite fabricated by cold rolling. Compos, Part B Eng. 2011;42(6):1468-73.

35. Xu H, Qin I, Clauberg H, Chylak B, Acoff VL. New observation of nanoscale interfacial evolution in micro $\mathrm{Cu}-\mathrm{Al}$ wire bonds by in-situ high resolution TEM study. Scr Mater. 2016;115:1-5.

36. Cheng FJ, Yao JF, Yang ZW, Wang Y, Xiao B. Structure and composition of oxide film on 5083 alloy at brazing temperature. Mater Sci Technol. 2015;31(11):1282-1289.

37. Lumley RN, Sercombe TB, Schaffer GM. Surface oxide and the role of magnesium during the sintering of aluminum. Metall Mater Trans, A Phys Metall Mater Sci. 1999;30(2):457-63.
38. Abbasi M, Karimi Taheri A, Salehi MT. Growth rate of intermetallic compounds in $\mathrm{Al} / \mathrm{Cu}$ bimetal produced by cold roll welding process. J Alloys Compd. 2001;319(1-2):233-41.

39. Han YQ, Ben LH, Yao JJ, Wu CJ. Microstructural characterization of $\mathrm{Cu} / \mathrm{Al}$ composites and effect of cooling rate at the $\mathrm{Cu} / \mathrm{Al}$ interfacial region. Int J Miner Metall Mater. 2015;22(1):94-101.

40. Han Y, Ben L, Yao J, Feng S, Wu C. Investigation on the interface of $\mathrm{Cu} / \mathrm{Al}$ couples during isothermal heating. Int J Miner Metall Mater. 2015;22(3):309-18.

41. Khan HA, Wang KF, Li JJ. Interfacial bonding mechanism and mechanical properties of micro friction stir blind riveting for multiple Cu/Al ultra-thin layers. Mater Charact. 2018;141:32-40.

42. Chang SY, Tsao LC, Li TY, Chuang TH. Joining 6061 aluminum alloy with Al-Si-Cu filler metal. J Alloys Compd. 2009;488(1):174-80.

43. Turriff DM, Corbin SF, Kozdras M. Diffusional solidification phenomena in clad aluminum automotive braze sheet. Acta Mater. 2010;58(4):1332-41.

44. Mazar Atabaki M, Idris J. Low-temperature partial transient liquid phase diffusion bonding of $\mathrm{Al} / \mathrm{Mg}_{2} \mathrm{Si}$ metal matrix composite to AZ91D using Al-based interlayer. Mater Des. 2012;34:832-41.

45. Xia CZ, Li Y, Puchkov UA, Gerasimov SA, Wang J. Microstructure and phase constitution near the interface of $\mathrm{Cu} / \mathrm{Al}$ vacuum brazing using Al-Si filler metal. Vacuum. 2008;82(8):799-804

46. Sohn WH, Bong HH, Hong SH. Microstructure and bonding mechanism of $\mathrm{Al} / \mathrm{Ti}$ bonded joint using $\mathrm{Al}-10 \mathrm{Si}-1 \mathrm{Mg}$ filler metal. Mater Sci Eng A. 2003;355(1-2):231-40.

47. Xie GQ, Ohashi O, Sato T, Yamaguchi N, Song MH, Mitsuishi $\mathrm{K}$, et al. Effect of $\mathrm{Mg}$ on the sintering of Al-Mg alloy powders by pulse electric-current sintering process. Mater Trans. 2004;45(3):904-13.

48. Bhadeshia HKDH. Joining of commercial aluminium alloys. In: International Conference on Aluminum; 2003; Bangalore, India. Proceedings. Bangalore: Aluminium Association of India; 2003. p. 195-204.

49. Mahmoudi Ghaznavi M, Ekrami A, Kokabi AH. Effect of solidification mechanism on microstructure and mechanical properties of joint in TLP bonded A12024-T6 alloy. Sci Technol Weld Join. 2011;16(2):174-80.

50. Feng J, Songbai X, Wei D. Reliability studies of $\mathrm{Cu} / \mathrm{Al}$ joints brazed with Zn-Al-Ce filler metals. Mater Des. 2012;42:156-63.

51. Chang YA. Phase diagram calculations in teaching, research, and industry. Metall Mater Trans, B, Process Metall Mater Proc Sci. 2006;37B(1):7-39.

52. Cheepu M, Susila P. Growth rate of intermetallics in aluminum to copper dissimilar welding. Trans Indian Inst Met. 2020;73(6):1509-14.

53. Braunovic M. Reliability of power connections. J Zhejiang Univ Sci A. 2007;8(3):343-56.

54. Zhou L, Li GH, Zhang RX, Zhou WL, He WX, Huang YX, et al. Microstructure evolution and mechanical properties of friction stir spot welded dissimilar aluminum-copper joint. J Alloys Compd. 2019;775:372-82. 